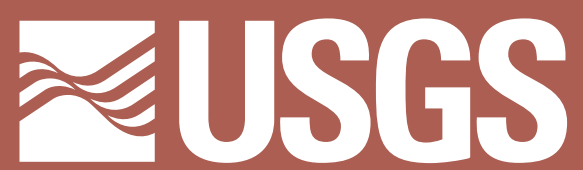

science for a changing world

\title{
Planning for the Conservation and Development of Infrastructure Resources in Urban Areas- Colorado Front Range Urban Corridor
}

U.S. Geological Survey Circular 1219 


\section{Planning for the Conservation and Development of Infrastructure Resources in Urban Areas- Colorado Front Range Urban Corridor}

Things Planners, Decision-Makers, and the Public Should Know

By USGS Front Range Infrastructure Resources Project

Daniel H. Knepper, Jr. (editor)

Contributors: Belinda F. Arbogast

L. Rick Arnold

Neil S. Fishman

William H. Langer

Carol S. Mladinich

James E. Roelle

David R. Wilburn

U.S. Geological Survey Circular 1219

U.S. Department of the Interior

U.S. Geological Survey 


\section{U.S. Department of the Interior \\ Gale A. Norton, Secretary}

\section{U.S. Geological Survey \\ Charles G. Groat, Director}

Free on application to

U.S. Geological Survey, Information Services

Box 25286, Federal Center

Denver, CO 80225

This publication is also available online at

http://geology.cr.usgs.gov/pub/circulars/c1219/

First printing 2002

Any use of trade, product, or firm names in this publication

is for descriptive purposes only and

does not imply endorsement by the U.S. Government

\section{Library of Congress Cataloging-in-Publication Data}

Planning for the conservation and development of infrastructure resources in urban areas-Colorado front range urban corridor : things planners, decision-makers, and the public should know / by USGS Front Range Infrastructure Resources Project : Daniel H. Knepper, Jr. (editor) ; contributors, Belinda F. Arbogast ... [et al.].

p. cm.-(U.S. Geological Survey circular ; 1219)

Includes bibliographical references.

1. Regional planning-Colorado. 2. City planning-Colorado. 3. Infrastructure (Economics)-Colorado-Planning. 4. Conservation of natural resources-Colorado. I. Knepper, Daniel H. II. Arbogast, B.F. (Belinda F.) III. Front Range Infrastructure Resources Project (U.S.) IV. Series.

HT393.C6 P53 2002

$363^{\prime} .09788-\mathrm{dc} 21$

2001054541

Published in the Central Region, Denver, Colorado

Manuscript approved for publication September 17, 2001

Cover art by John M. Evans

Graphics by authors and Gayle M. Dumonceaux

Photocomposition by Gayle M. Dumonceaux 


\section{Contents}

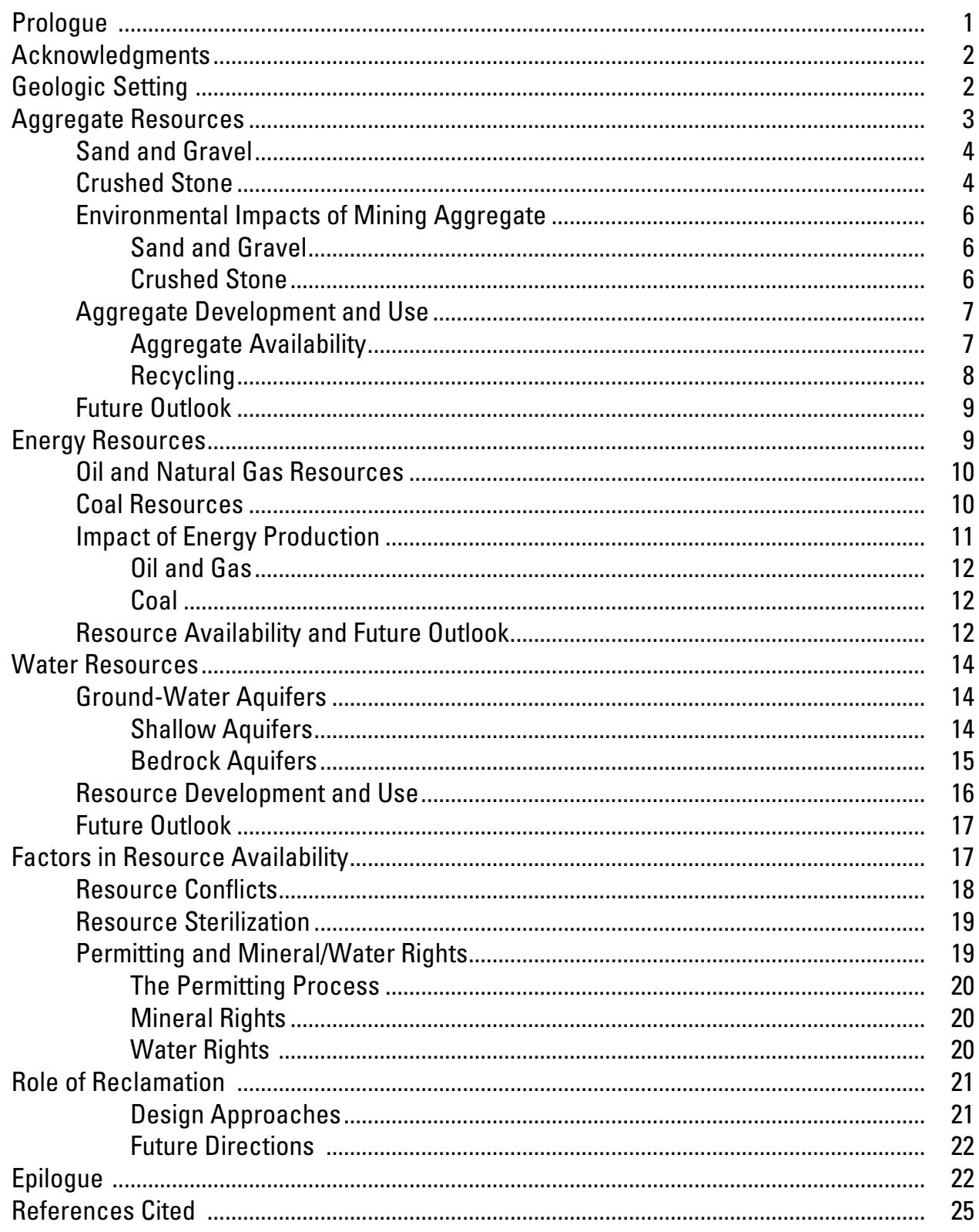




\section{Figures}

1. Index map of Front Range Infrastructure Resources Project (FRIRP) area ......... 2

2. Generalized lithologic map of Front Range Infrastructure Resources

Project area

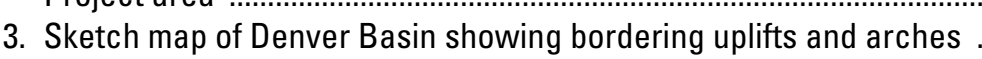

4. Block diagram illustrating landforms associated with the four types of alluvial sand and gravel deposits in project area

5. Photograph of typical Quaternary floodplain and low terrace sand and gravel deposit along Cache la Poudre River near Greeley, Colo.

6. Photograph of Specification Aggregate Quarry (Lafarge Corporation) near Golden, Colo.

7. Chart of Colorado aggregate production and population growth for 1951 through 1997

8. Photograph of on-site recycling of demolition debris for use as aggregate

at the former Cinderella City shopping mall in Denver, Colo. ........................... the Boulder-Weld coal field and Foothills district coal producing areas relative to the Front Range Infrastructure Resources Project area

10. Stratigraphic column of major petroleum source and reservoir rocks in Denver Basin and equivalent units as shown on figure 2

11. Photograph of Cretaceous petroleum source (Skull Creek Shale) and reservoir (Muddy ("J") Sandstone) rocks

12. Aerial photograph of ground over coal mine subsidence .................................... 13

13. Photograph of new residential community north of Denver, sharing its neighborhood with oil production activity in Wattenberg area

14. Sketch showing distribution of water in unconsolidated sediments of a shallow aquifer deposited on impermeable bedrock

15. Landsat Thematic Mapper image showing approximate center of ancestral

South Platte River paleovalley east of present course of river

16. Chart showing geohydrologic characteristics of bedrock aquifers in project area

17. Sketch showing confined and unconfined conditions in bedrock aquifers of Denver Basin

18. Photograph of established oil well pump jack in an actively developing residential area

19. Aerial photograph of WREN Pit along Cache la Poudre River near Fort Collins, Colo., during initial flooding

20-23. Photographs of:

20. Reclaimed mining landforms in Denver urban area ...

21. Storage area for shipping containers on a landfill graded to match the surrounding area along Interstate 76

22. An older sanitary landfill in an exhausted sand and gravel pit near Interstate 76 and Pecos Street that requires vents to allow methane gas to escape.

23. Reclaimed sand and gravel mining operations in Clear Creek valley at Prospect Park, Wheatridge, Colo. 


\title{
Planning for the Conservation and Development of Infrastructure Resources in Urban Areas- Colorado Front Range Urban Corridor
}

\section{Things Planners, Decision-Makers, and the Public Should Know}

\author{
By USGS Front Range Infrastructure Resources Project
}

\section{Prologue}

Infrastructure resources are the basic physical materials needed to support the development, maintenance, and growth of a society. Natural aggregate for construction, energy for fuel, and water for domestic and commercial use are primary infrastructure resources. Indeed, wherever people live, work, and travel, infrastructure resources are critical ingredients for sustaining a thriving society and maintaining a high quality of life in the United States.

In 1996, the Director of the U.S. Geological Survey initiated a 5-year study to develop methods for assessing infrastructure resources and to characterize the location, distribution, and quality of the infrastructure resources of a part of the Colorado Front Range urban corridor between Denver and Fort Collins, Colorado. The Front Range Infrastructure Resources Project (herein called the project) has completed its primary task and gone on to identify geosocietal and environmental factors that influence the availability of these resources as well.

The Colorado Front Range urban corridor between Denver and Fort Collins is a prime example of a region that has been shaped by its natural resources. The region has evolved through a series of booms and busts-beaver furs, gold and silver, cattle, coal, oil and gas - and now treasures perhaps its most precious commodity, the "Colorado lifestyle." In Colorado's early years its beauty and natural resources must have seemed inexhaustible. These qualities have drawn people to Colorado, and the Front Range urban corridor in particular, which is now being threatened by the rapidly growing population.

As population centers grow outward and become interconnected, infrastructure resources may become fragmented, depleted, or precluded from use, while natural vegetation, open spaces, wetlands, and wildlife habitat are lost. Political, social, and economic considerations strongly influence whether land is used to supply resources or is put to other uses such as parks and recreational facilities, residential and commercial development, open space, or agriculture. Planners, decision-makers, and the public face difficult choices, some of which may be irreversible.

Making informed decisions requires access to critical data and an understanding of the social and economic implications of possible decision scenarios. The Front Range Infrastructure Resources Project has prepared technical reports characterizing the infrastructure resources in the project area and digital datasets showing the location and distribution of resources that are suitable for analysis using modern Geographic Information Systems (GIS). A highly flexible Decision Support System (DSS), based on the widely used ArcView software, was developed to illustrate how the project's data could be used in the planning process (Langer and others, 1999). Most of the project's technical reports and digital datasets are cited in the following discussions and are available from the USGS. All of the products produced by the project are described in the project's annotated bibliography (Knepper, 2001); for detailed information the reader is directed to one or more of these published reports.

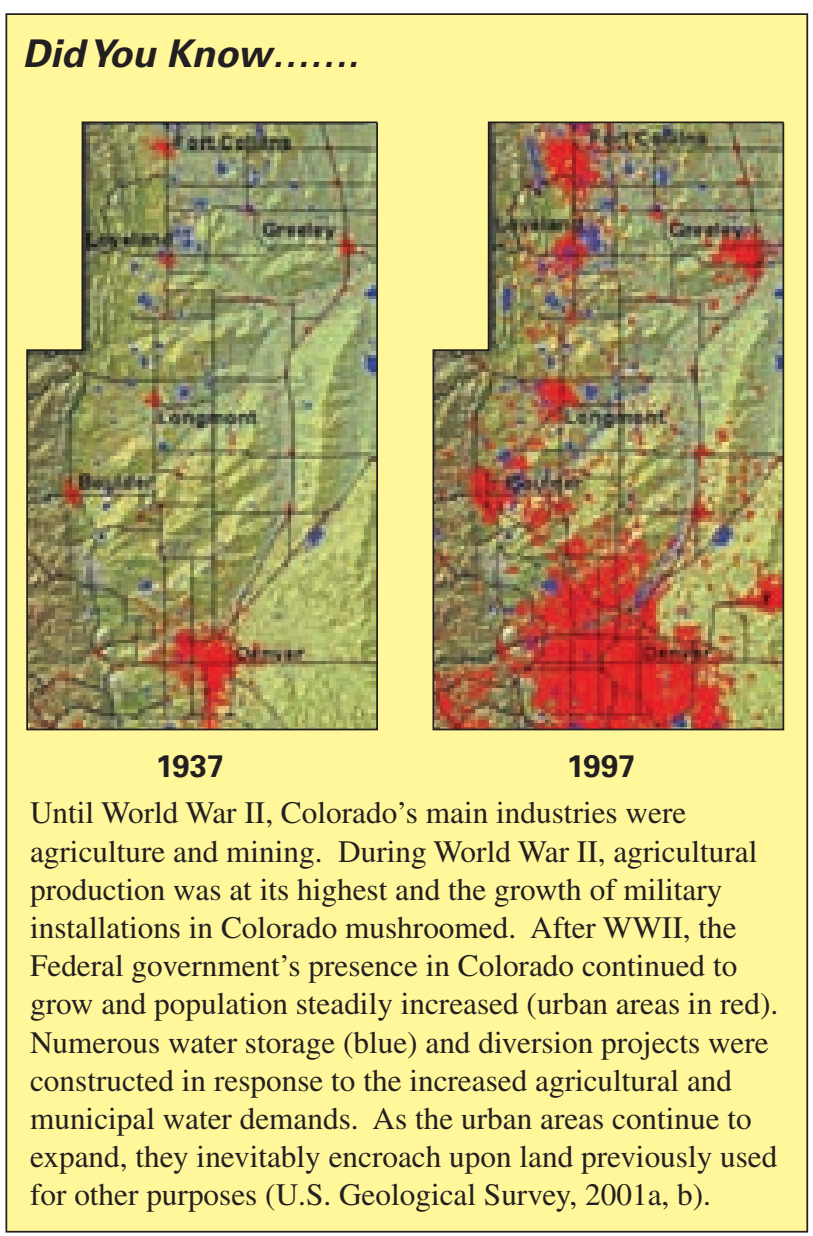


This Circular will provide the reader with a basic understanding of the characteristics, location, distribution, and quality of infrastructure resources in the project area. With this understanding, the reader will then explore the many factors that affect the current and future availability of these resources in the project area, including the socioeconomic aspects of the resources and the complexly interwoven individual and collective interests that policy-makers, decision-makers, and the public must address. Finally, the reader will learn about past mining reclamation practices in the project area and how innovative reclamation designs that are functional or aesthetically pleasing may actually serve to make local aggregate sources available while helping to preserve or establish development, open space, water storage and recreational facilities, and wildlife habitat.

\section{Acknowledgments}

The Front Range Infrastructure Resources Project thanks our stakeholders and collaborators for their critical input to the direction and emphasis of project research and their contributions toward the successful completion of that research. The project extends a very special thanks to our now-retired USGS colleagues David A. Lindsey, L. David Nealey, and Stanley G. Robson and to James A. Cappa (Colorado Geological Survey) for their hard work and enthusiasm in helping to pull the multidisciplinary pieces of the project together during its initial phase and for providing guidance during the course of the project. The contributors to this Circular acknowledge the numerous project scientists and technicians upon whose work much of this Circular is based. And finally, special thanks go to David A. Lindsey (USGS), Nancy J. Knepper (Denver Museum of Nature and Science), and Alex J. Donatich (USGS) for thoughtful technical reviews and editing of the Circular manuscript that helped to meld the diverse scientific, technical, and geosocietal information into a coherent document.

\section{Geologic Setting}

The Front Range Infrastructure Resources Project focused its research efforts on an area covering 45 USGS 7.5-minute topographic quadrangles in north-central Colorado along the rapidly growing Colorado Front Range urban corridor between Denver and Fort Collins, Colo. (fig. 1). Most of the area is in the Great Plains, but includes the foothills of the Colorado Front Range at its western edge.

The oldest rocks in the area are crystalline rocks formed during the Precambrian between 1.7 and 1.0 billion years ago (Hedge and others, 1967; Hedge, 1969). These rocks are only exposed in the mountains in the Front Range, but are present at depth and form the basement surface upon which younger sedimentary rocks were deposited throughout the area (fig. 2). The Precambrian crystalline rocks include rocks formed by the crystallization of molten rock emplaced deep in the crust (igneous rocks) and by the deep burial and recrustallization by heat and pressure of rocks deposited at the Earth's surface (metamorphic

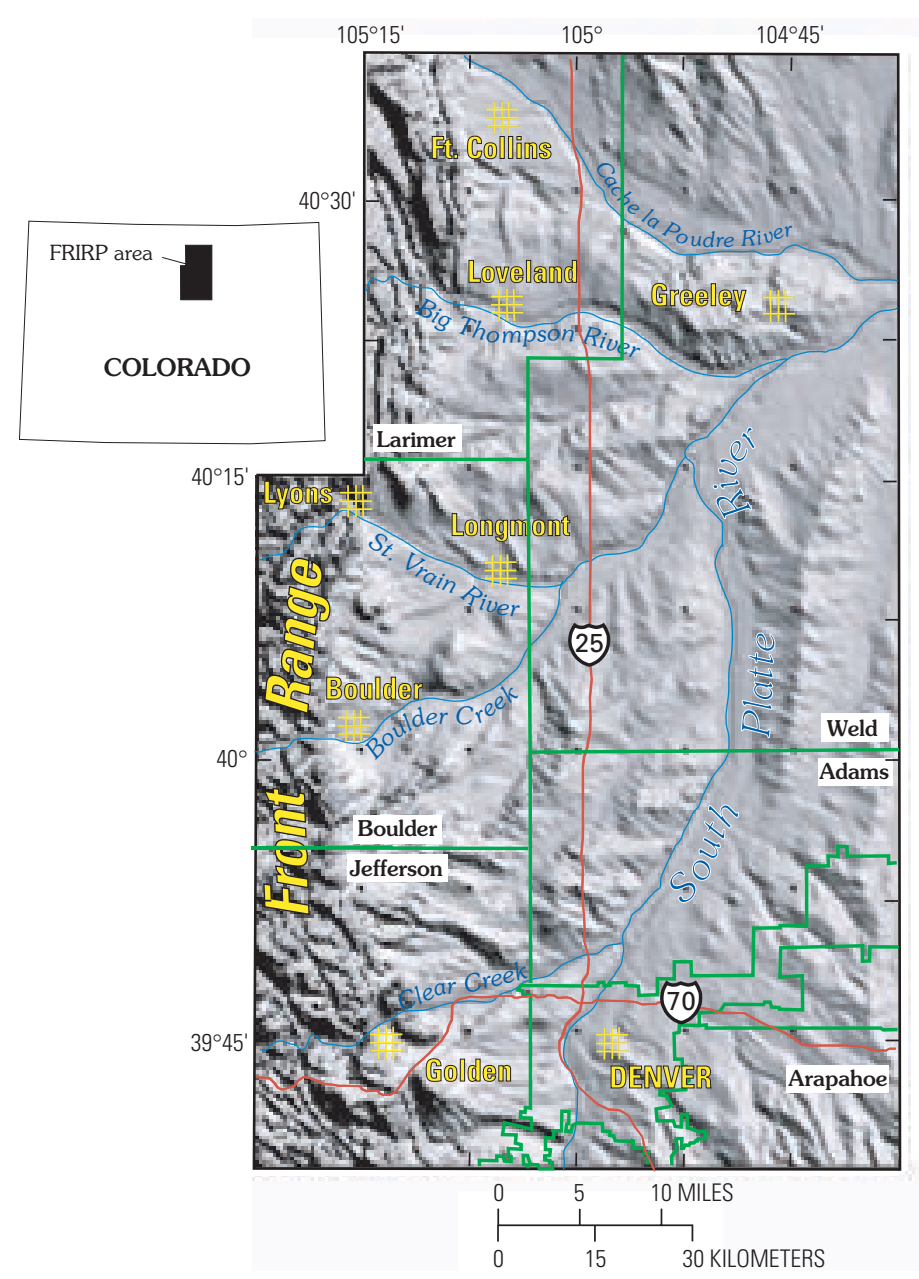

Figure 1. Index map of Front Range Infrastructure Resources Project (FRIRP) area. Area consists of 45 U.S. Geological Survey 1:24,000-scale $\left(7.5^{\prime}\right)$ topographic quadrangles along Denver-Greeley-Fort Collins section of Front Range urban corridor.

rocks). Precambrian igneous rock types in the Front Range include granite, granodiorite, monzanite, diorite, and pegmatite. The most common metamorphic rocks in the Front Range are gneiss, schist, amphibolite, and quartzite.

Overlying the Precambrian crystalline rocks is a thick sequence of sedimentary strata ranging in age from Paleozoic to Tertiary (fig. 2). These strata are mostly sandstone, shale, siltstone, conglomerate, and thin limestone units. These rocks contain the coal, the source and reservoir rocks for the oil and natural gas, and the bedrock aquifers that provide high-quality drinking water in the Front Range region.

During the Laramide orogenic event, which lasted from approximately 79 to 39 million years ago (Tweto, 1975;

Weimer, 1996), the large block of Precambrian crystalline rocks that is now the Colorado Front Range was uplifted along a series of large faults parallel to the mountain front. The overlying sedimentary rocks were also uplifted and tilted. Erosion has removed the sedimentary rocks from the uplifted block, but at the mountain front the sedimentary rocks are steeply tilted to the east along the edge of the uplift. The harder, more resistant rocks, mostly sandstones and conglomerates, form prominent hogback ridges parallel to the mountain front. 


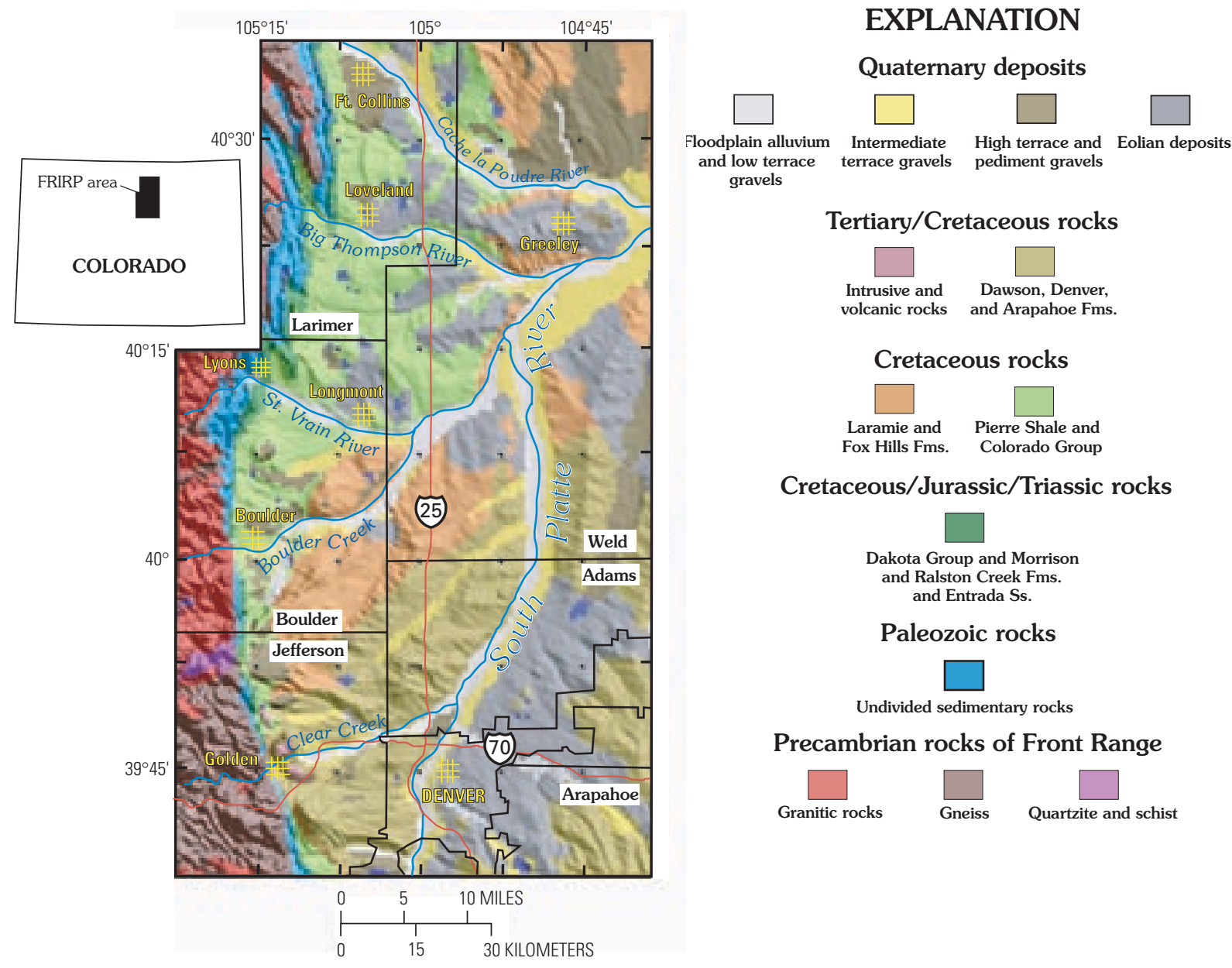

Figure 2. Generalized lithologic map of Front Range Infrastructure Resources Project (FRIRP) area (modified from Knepper and others, 1999).

A few miles to the east, these same sedimentary strata are far beneath the present-day surface and are nearly horizontal. At the eastern edge of the project area, the sedimentary strata dip gently to the west, back toward the mountains. Regionally, this configuration of sedimentary strata is an asymmetrical, oblong bowl elongated in a north-south direction. This bowl-shaped structure, which extends north, south, and east well beyond the project area, is called the Denver Basin (fig. 3).

During and subsequent to mountain building in the Cretaceous and Tertiary, shallow intrusive and volcanic igneous rocks were emplaced at various locations in the western part of the project area. Generally, these rocks are hard and dense and have been sources for high-quality crushed stone aggregate.

The youngest geologic units in the project area are unconsolidated sediments of Quaternary age (fig. 2). There are two types of deposits of unconsolidated sediments: alluvial deposits of sand and gravel associated with the modern streams and their predecessors, and eolian (windblown) deposits of silt and sand. These deposits, especially the alluvial gravels, are important sources of construction materials and ground water in the area.

The major stream in the area is the northeasterly flowing South Platte River (fig. 2). The major tributaries to the South Platte River, including Clear and Boulder Creeks and the St. Vrain, Big Thompson, and Cache la Poudre Rivers, originate at an elevation of nearly $14,000 \mathrm{ft}$ in the Front Range far to the west of the project area near the Continental Divide. During the Pleistocene ("Ice Age"), glaciers in the mountains provided large amounts of meltwater that rushed eastward down the steep, narrow canyons of the Front Range carrying boulders, cobbles, and pebbles eroded from the mountains. When these high-energy streams exited the mountains onto the plains, the carrying capacity of the streams was reduced and sand and coarse gravels were deposited along their valleys. The oldest of these alluvial deposits are the high terrace and pediment gravels formed by predecessors of the modern streams; only remnants of these once more extensive deposits are preserved in the project area (fig. 2). The younger alluvial deposits, including the floodplain alluvium and low terrace gravels and the intermediate terrace gravels units of figure 2, closely follow the modern stream courses and represent several periods of alluvial deposition.

\section{Aggregate Resources}

Aggregate is an essential component of Portland cement and asphaltic concrete, road base, and many other construction 


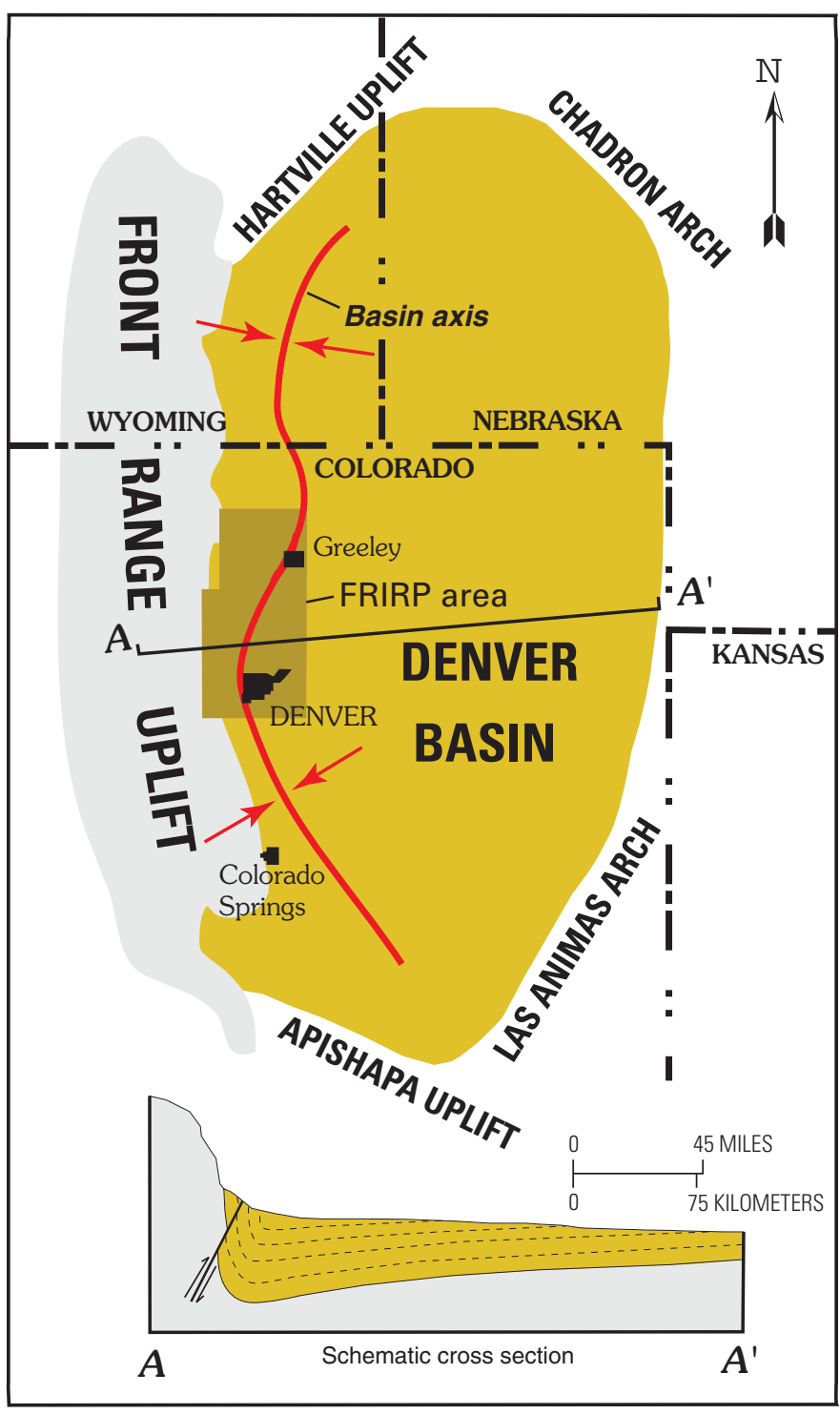

Figure 3. Regional extent of Denver Basin showing bordering uplifts and arches. Synclinal axis (red) is structurally deepest part of basin and trends through the Front Range Infrastructure Resources Project (FRIRP) area.

applications. About 80 percent of Colorado's aggregate is sand and gravel from floodplains and terraces along stream valleys, or occasionally from high dissected terraces and alluvial fans along the mountain front (fig. 2). About 20 percent of Colorado's aggregate is crushed stone produced from rock quarries in Precambrian crystalline rocks in the mountains or Tertiary volcanic and shallow intrusive igneous rocks that form buttes or mesas in the foothills along the mountain front.

\section{Sand and Gravel}

Lindsey (1997) described four general types of sand and gravel deposits in the Colorado Front Range urban corridor (fig. 4): alluvial fans, high dissected terraces, intermediate terraces, and floodplains and low terraces. Floodplains and low terraces of major streams are the principal sources of high-quality sand

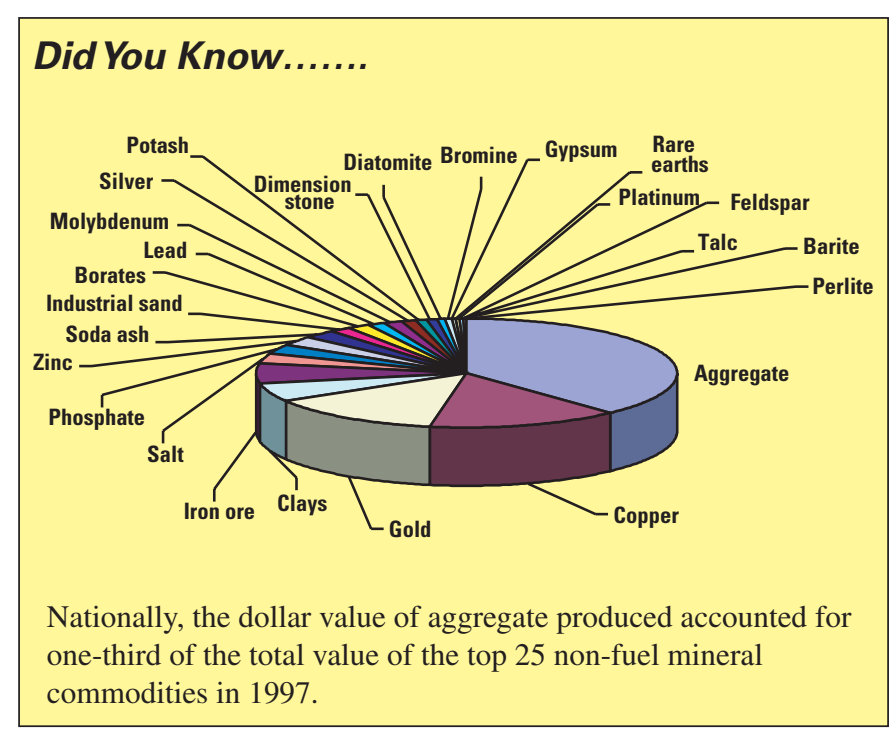

and gravel aggregate recovered in the project area (fig. 2). Sand and gravel underlying intermediate terraces may also be used as aggregate, but their quality is commonly lower than that of underlying floodplains and low terraces. Gravel in alluvial fan and high dissected terrace deposits is not commonly used as high-specification aggregate because they are often deeply weathered and lack the hardness and density of high-quality aggregate.

Gravel deposits of the project area are mostly Quaternary in age (as old as 2 million years). During the Quaternary, the mountainous terrain to the west underwent repeated glaciations. Glaciers eroded the mountains, and meltwater streams transported the eroded rock debris eastward to the Great Plains. Consequently, gravels in the project area are largely restricted to major streams with headwaters deep in the mountains. These streams include the South Platte River, Clear Creek, Boulder Creek, St. Vrain Creek, the Big Thompson River, and the Cache la Poudre River (fig. 5). Much of the coarse gravel was deposited near the mountain front, and the amount and size of coarse particles generally decrease downstream away from the mountains (Langer and Lindsey, 1999). However, gravels along the South Platte River valley get locally coarser where high-energy tributary streams joined the river and provided an influx of coarse gravel. Deposits along streams that have their headwaters on the plains commonly lack coarse gravel.

\section{Crushed Stone}

Crushed stone aggregate is manufactured from bedrock and must meet rigid specifications. Ideal crushed stone for construction use should be: (1) strong and resistant to rough handling and use, (2) physically stable under wet and dry conditions and through freeze/thaw cycles, and (3) not chemically reactive with cement.

To produce crushed stone aggregate, rock is first drilled and blasted. Blasting breaks the rock into pieces suitable for crushing. The blasted material is extracted using conventional earth-moving equipment and then transported, either by truck or 


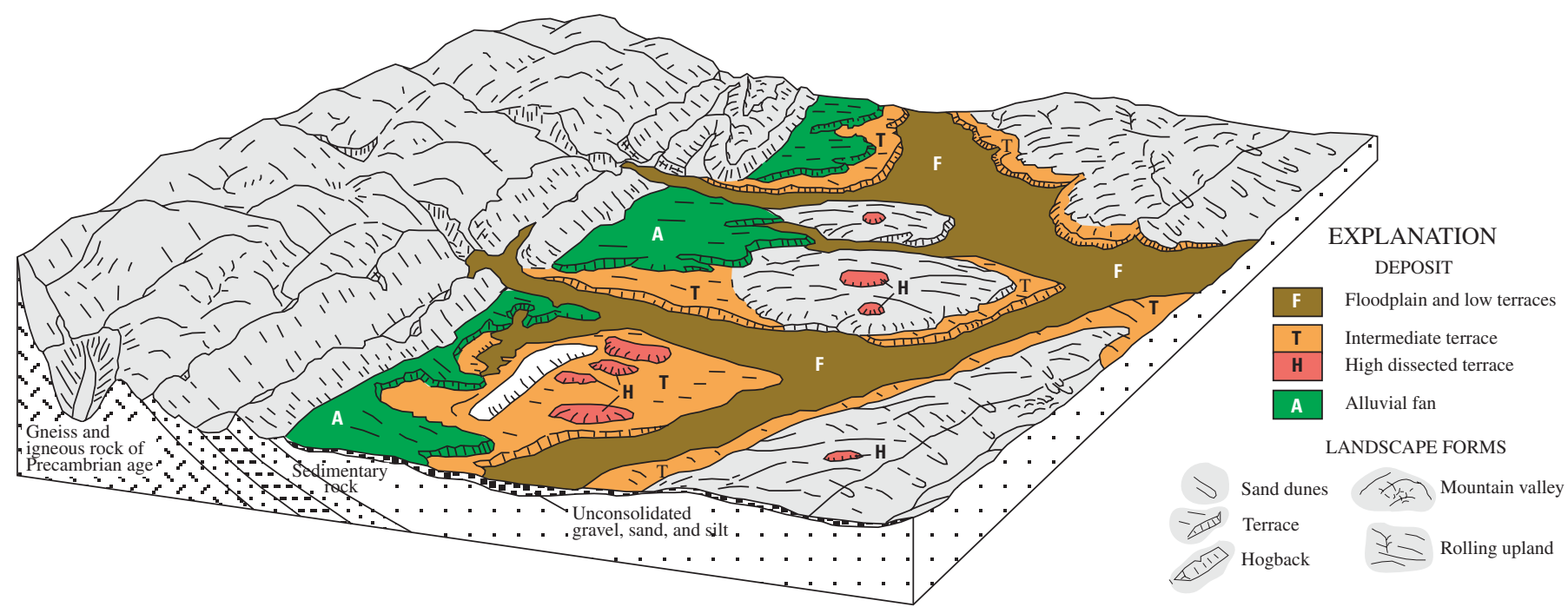

Figure 4. Block diagram illustrating landforms associated with the four types of alluvial sand and gravel deposits in the project area (modified from Crosby, 1978).

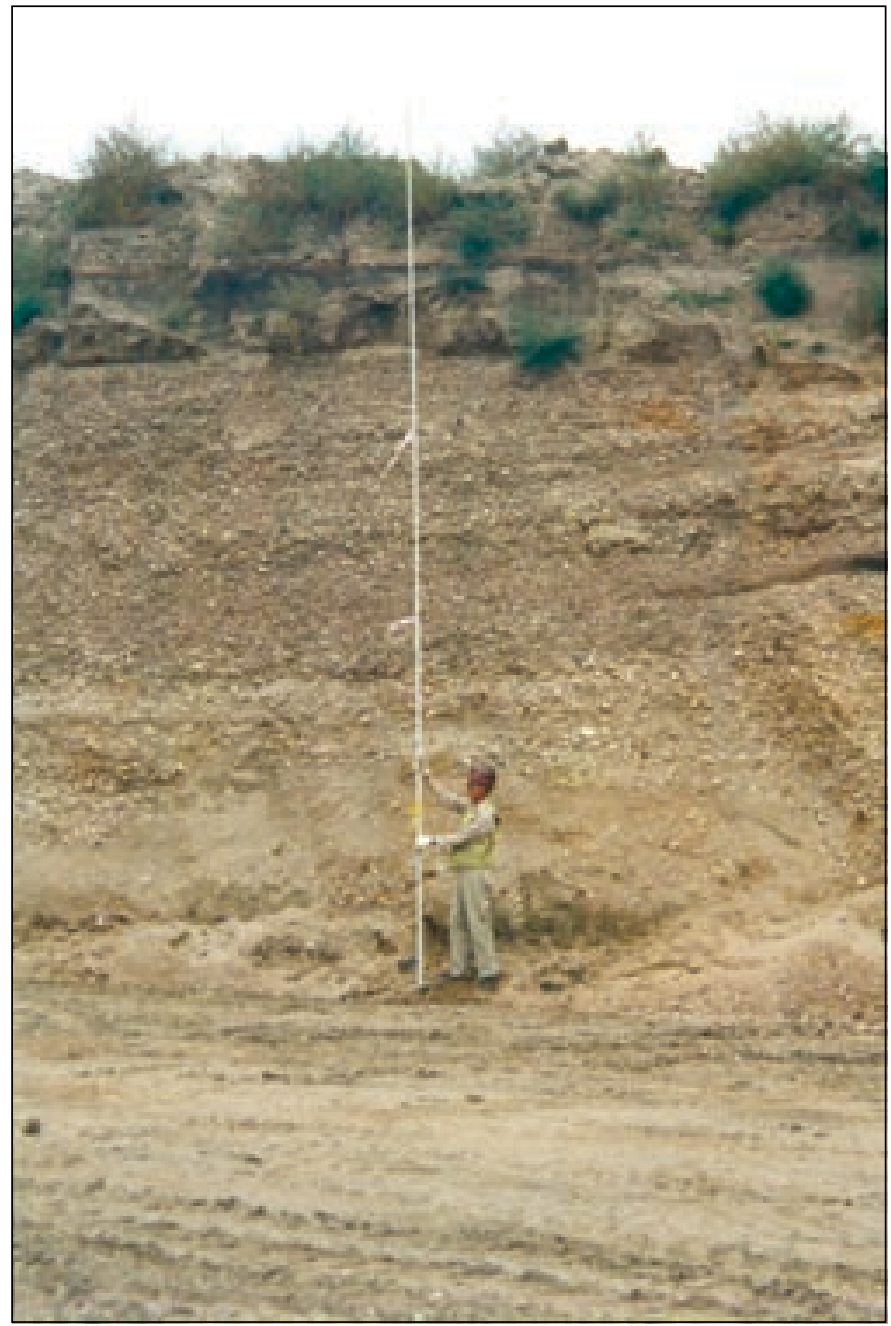

Figure 5. Typical Quaternary floodplain and low terrace sand and gravel deposit nearly $25 \mathrm{ft}$ thick exposed in wall of Lafarge 35th Street Pit along Cache la Poudre River near Greeley, Colo. (Langer and Lindsey, 1999). conveyor, to a processing plant where it is crushed, washed, and sorted by size.

Most crushed stone in the project area is quarried in the mountains and foothills in Jefferson, Boulder, and Larimer Counties. Three broad categories of Precambrian crystalline rocks occur in the mountains: gneiss, quartzite and schist, and granitic rocks (fig. 2). The gneiss and the quartzite and schist units are metamorphic rocks formed by the recrystallization of preexisting sedimentary and volcanic rocks by heat and pressure during deep burial. Gneiss has a highly variable mineralogy, grain size, and texture (fig. 6), but generally is hard, durable, and physically and chemically stable, and produces high-quality crushed stone. Interlayered quartzite and schist form a distinctive rock unit in the mountains between Golden and Boulder (fig. 2). The schist layers contain a large percentage of soft micaceous minerals that make the rock break into thin, slabby pieces that are unsuitable for crushed stone. The quartzite layers are primarily composed of interlocking crystals of quartz, which makes the rock extremely hard. The quartzite also is physically and chemically stable and would make high-quality crushed stone, but has never been commercially produced.

Precambrian granitic rocks (fig. 2) are the dominant rock type exposed in the mountains north of Jefferson County and have been used for crushed stone. These igneous rocks crystallized from molten rock emplaced into the metamorphic rocks deep in the crust. Although shown as a single unit on figure 2, the unit actually consists of several large rock bodies emplaced at different times in the Precambrian. The mineralogy and texture are highly variable within and between each rock body, so their suitability as sources of crushed stone must be evaluated at each potential site.

Fine-grained igneous rocks of Tertiary age occur at various places in the sedimentary strata along the mountain front between Golden and Lyons, Colo. (Van Horn, 1957; Colton and Fitch, 1974). Exposures of these rocks are generally too small to show on figure 2, except near Golden where volcanic flows 


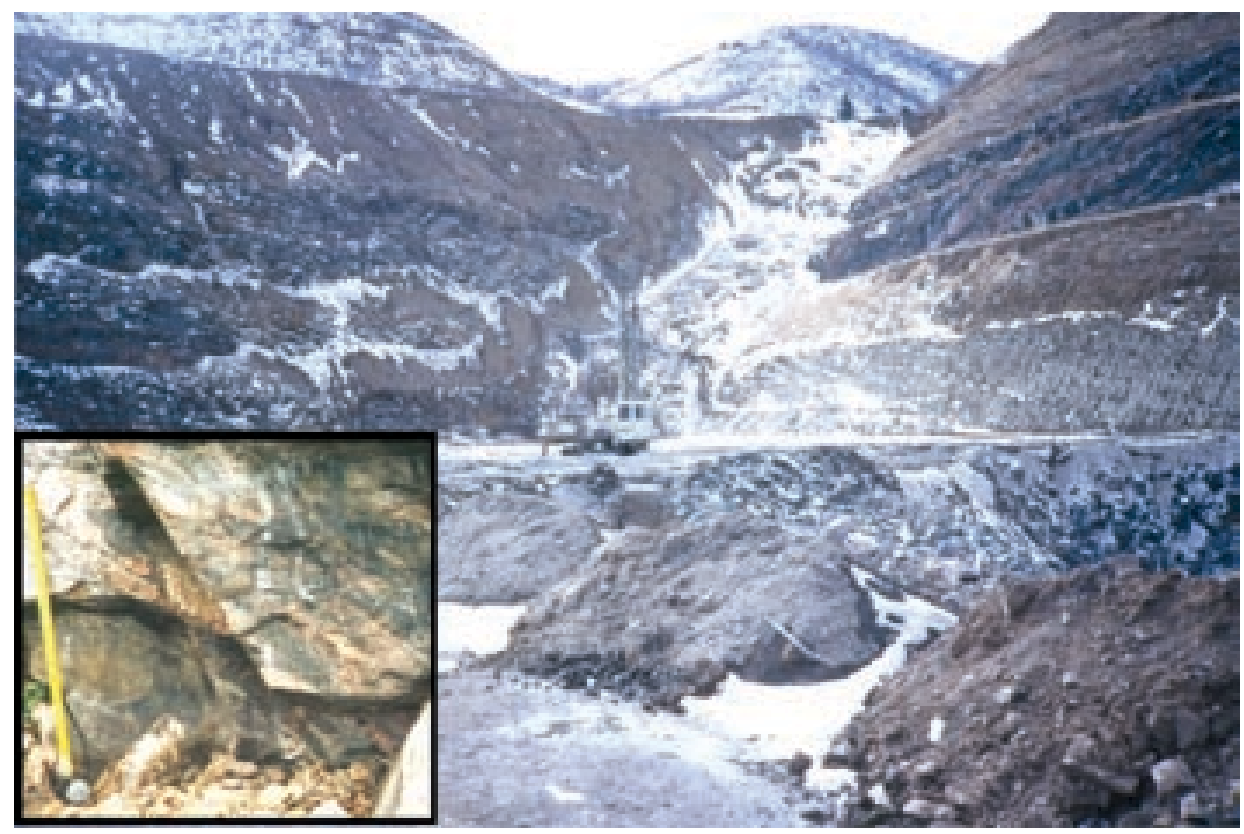

Figure 6. Specification Aggregate Quarry (Lafarge Corporation) near Golden, Colo., mines Precambrian banded gneiss for making crushed stone. Highwalls and benches indicate volume of material already mined. Drill rig (center) is preparing holes for blasting charges. Inset shows closeup of pink and black banded gneiss crushed at quarry.

cap North Table and South Table Mountains; the feeder vent for these flows is exposed at Ralston Butte 1.5 mi north of North Table Mountain. The Tertiary igneous rocks in the project area have a broad range in composition, but generally are potential sources for high-quality crushed stone. Crushed stone quarries are currently operating at Ralston Butte and southwest of Lyons.

\section{Environmental Impacts of Mining Aggregate}

Most environmental impacts associated with aggregate mining are benign. Extracting aggregate seldom produces toxic materials like those often associated with the mining of metals or the production of energy resources. The most obvious environmental impact of aggregate mining is the conversion of land use, most likely from undeveloped or agricultural to a hole in the ground. This major impact is accompanied by loss of habitat, noise, dust, blasting effects, erosion, sedimentation, and scenic changes. Some of the impacts are short-lived and most can be predicted and easily observed. Most impacts can be controlled, mitigated, or kept at tolerable levels and can be restricted to the immediate vicinity of the aggregate operation by using responsible operational practices. Others, such as effects on the water table, may challenge aggregate producers.

\section{Sand and Gravel}

Sand and gravel are excavated in the project area using dry and wet mining techniques. If the excavation does not penetrate the water table, the gravel is mined dry and extracted by using conventional earth-moving equipment, such as bulldozers, front loaders, and track hoes. If the excavation penetrates the water table, water must be pumped or otherwise removed from the pit. The pit becomes a discharge point, which may lower the water table near the operation, in turn impacting nearby wells, lakes, and streams. In highly permeable deposits, slurry walls might be necessary to isolate the pit from the water table. Water removed through dewatering can be returned to nearby streams, which may minimize the impacts that dewatering can have on the overall hydrologic system. Observation wells allow monitoring of impacts on the water table. In some situations, a pit may not be able to be drained or the operator may prefer to extract the material by wet mining techniques. Material may be excavated by using draglines, clamshells, bucket and ladder, or hydraulic dredges. The greatest potential impact of mining a wet pit occurs when the pit is located on an active floodplain, where spring runoff may result in flooding and capture of the pit (Langer and Lindsey, 1999).

\section{Crushed Stone}

Rock quarries along the Colorado Front Range are commonly mined dry. Even though some quarries penetrate the water table, discharge to the quarry is generally low enough that the rate of evaporation exceeds the rate of discharge and active dewatering measures are not needed. The quarry may impact the water table, but these impacts are difficult to predict because behavior of ground-water flow in fractured rock is complex.

Most environmental impacts associated with producing crushed stone are engineering-related and typical of nearly any 
construction project: heavy equipment, noise, dust. This type of impact is restricted to the site, easy to predict, and easy to control using standard engineering techniques.

\section{Aggregate Development and Use}

Aggregate demand and production in the project area over the last 50 years have been driven by construction to support a steadily increasing population, with periodic surges in response to major Federal, State, and city construction projects (fig. 7). The 1950's and 1960's were a period of increasing production of construction aggregate throughout Colorado, primarily for large Federal Government projects. Much of the Interstate Highway System in Colorado, funded by the Federal Aid Highway Act of 1953 and Highway Revenue Act of 1956, was built from 1953 to 1974. Other infrastructure (roads, bridges, airports, and dams) still in use today was conceived or constructed during this period. Infrastructure built during the 1950's and 1960's supported continued population growth during the early 1970's. The building boom of the late 1970's was followed by an economic recession in the early 1980 's, which was marked by a decline in commercial construction throughout Colorado. In spite of this construction downturn, both sand and gravel and crushed stone production grew as continued population growth sustained the need for residential construction and related infrastructure. Commercial development projects during the early 1990's stimulated the Colorado construction industry as well as growth of suburban communities in the project area. Commercial construction in the Denver metropolitan area continued into the late 1990's and population growth in the project area continues to foster commercial and residential construction.

For the most part, local aggregate producers in the project area have been able to meet local demand over the last 50 years of growth. One large exception was during the construction of Denver International Airport in the early 1990's, when supplemental aggregate was hauled from Wyoming to Denver by rail because local producers could not meet the huge demand from airport construction and still satisfy regular customers. Whether future aggregate demand can be met by local producers is a growing concern. Although there is an abundance of potential aggregate resources in the project area, many of them are no longer accessible for extraction. Expanding population centers have built out and gradually encroached on existing deposits, thus rendering many nearby resources inaccessible. Zoning restrictions, land use conflicts, environmental concerns, and public opposition to mining are also making acquisition, permitting, and development of nearby aggregate resources increasingly difficult.

\section{Aggregate Availability}

For nearly 45 years, the possibility of future local aggregate resource shortages in the Colorado Front Range urban corridor has been recognized. In 1957, the Colorado Sand and Gravel Producers Association called attention to the diminishing sand and gravel resources available in the Denver area. Ten years

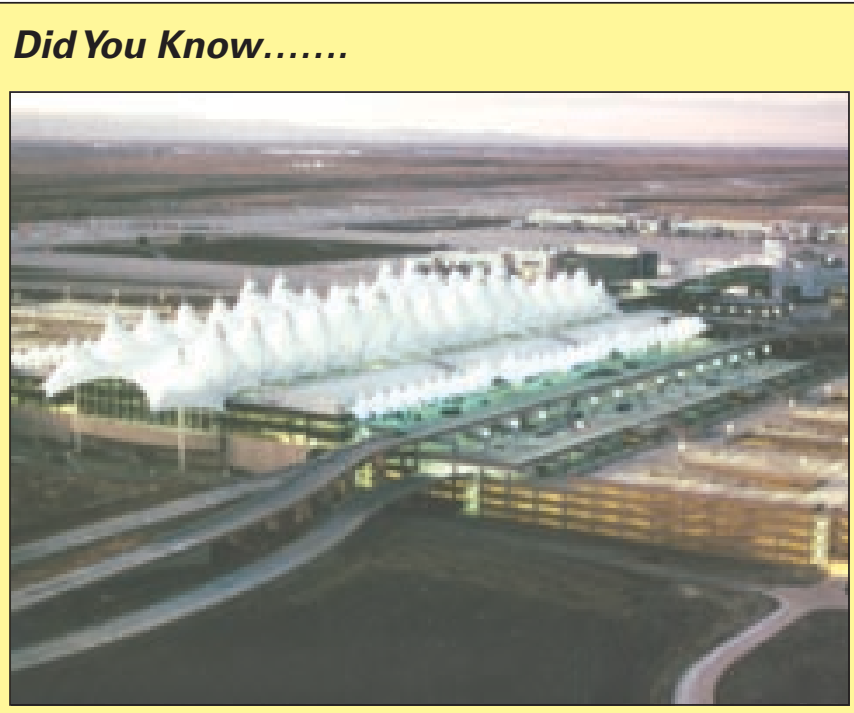

An estimated 10 million tons of aggregate were required for the concrete used in the construction of Denver International Airport. Over one-half of this aggregate went into the runways and aprons. The rest was used in constructing buildings, roadways, and bridges servicing the new airport.

later, the U.S. Bureau of Mines (Sheridan, 1967) predicted that restrictive zoning, lack of general public understanding of sand and gravel occurrence and mining operations, and conflicting land uses would soon create a shortage of convenient, low-cost aggregate in the Denver area.

During 1973, the Colorado legislature officially recognized the problem and passed House Bill 1529 (Section 34-1 in CRS, 1973). That act declared that: (1) the State's commercial mineral deposits were essential to the State's economy, (2) the populous counties of the State faced a critical shortage of such deposits, and (3) such deposits should be extracted according to a rational plan, calculated to avoid waste and cause the least practical disruption to the ecology and quality of life of the citizens. The U.S. Department of Labor (1981) pointed out that H.B. 1529 did not succeed in protecting existing aggregate resources, and that their availability in the Front Range area continued to decline. It blamed the decline on the fact that H.B. 1529 had no enforcement provisions. It also stated that restrictive zoning regulations, implemented to address environmental and visual concerns, were partly driven by the poor manner in which some rogue producers conducted business. During 1975, as a possible consequence of the lack of enforcement provisions in H.B. 1529, Western Paving Construction Company began using unit trains to haul gravel over $40 \mathrm{mi}$ from its loading site at Lyons, Colo., to its asphalt plant on Clear Creek at Pecos Street in Westminster, Colo. Gravel currently is transported over $60 \mathrm{mi}$ to Denver by rail from a site near Carr, Colo.

Prior to the 1980's, gravel production along the South Platte River was between Denver and the mountain front to the west; the deposits were about 50 percent gravel and 50 percent sand. During the 1980's, sand and gravel operators opened new facilities downstream (north) of Denver. These newly opened deposits were only about 20 percent gravel and required more land area and more processing to produce a comparable amount 
of gravel aggregate, generated more waste material, and required a longer transport to market, resulting in a more costly product.

As early as 1905, Colorado aggregate producers began supplementing sand and gravel aggregate with quarried crushed stone (Schwochow, 1980). Production of crushed stone in Colorado has steadily increased over the last 50 years (fig. 7), but today crushed stone is more than just a substitute for sand and gravel aggregate. Specifications for some applications, such as airport runways, require the use of crushed stone. Similarly, crushed stone aggregate is typically required for asphalt highways to achieve proper binding with the asphalt and meet specified strength parameters. Highways constructed with Federal funds must meet rigid specifications that require the use of sand manufactured from crushed rock and specifically prohibit the use of natural sand.

Five crushed stone quarries operate in the project area today. The Specification Aggregate Quarry (Lafarge Corporation) on Jackson Gulch south of Golden, the Strain Gulch Quarry (Aggregate Industries) south of Morrison, and the Colorado Lien Inc. Quarry in northern Larimer County produce crushed stone from Precambrian gneiss in the Front Range. The Asphalt Paving Company Quarry at Ralston Butte north of Golden and the Andesite Rock Company Quarry southwest of Lyons produce crushed stone from fine-grained Tertiary igneous rock in the foothills along the mountain front. To further help meet local demand, unit trains haul crushed stone to the Denver market area from the Granite Canyon Quarry (Meridian Aggregates Co.) west of Cheyenne, Wyo., to two distribution yards in the Denver area. A proposal to establish a new crushed stone quarry in the project area near Eldorado Canyon in northern Jefferson County was rejected by the county in 2001 .

Future growth, transportation, and land use planning will be affected by the ability of the aggregate industry to meet future demand for high-quality aggregate resources. Increased environmental awareness, public opposition, and stricter zoning regulations have made it more difficult to acquire, permit, and mine natural aggregate. Although urbanization has increased the demand for construction aggregate, it also has increased the quantities of construction debris that may provide a source of recycled aggregate.

\section{Recycling}

Recycled materials consist of construction and demolition debris from antiquated infrastructure such as buildings, roads, bridges, runways, sidewalks, and parking lots. Except during wars and earthquakes, the supply material for recycling is determined by physical degradation (for example, the typical life of asphalt roads is about 30 years, with routine maintenance), loss of economic utility, or a change in land use priorities (for

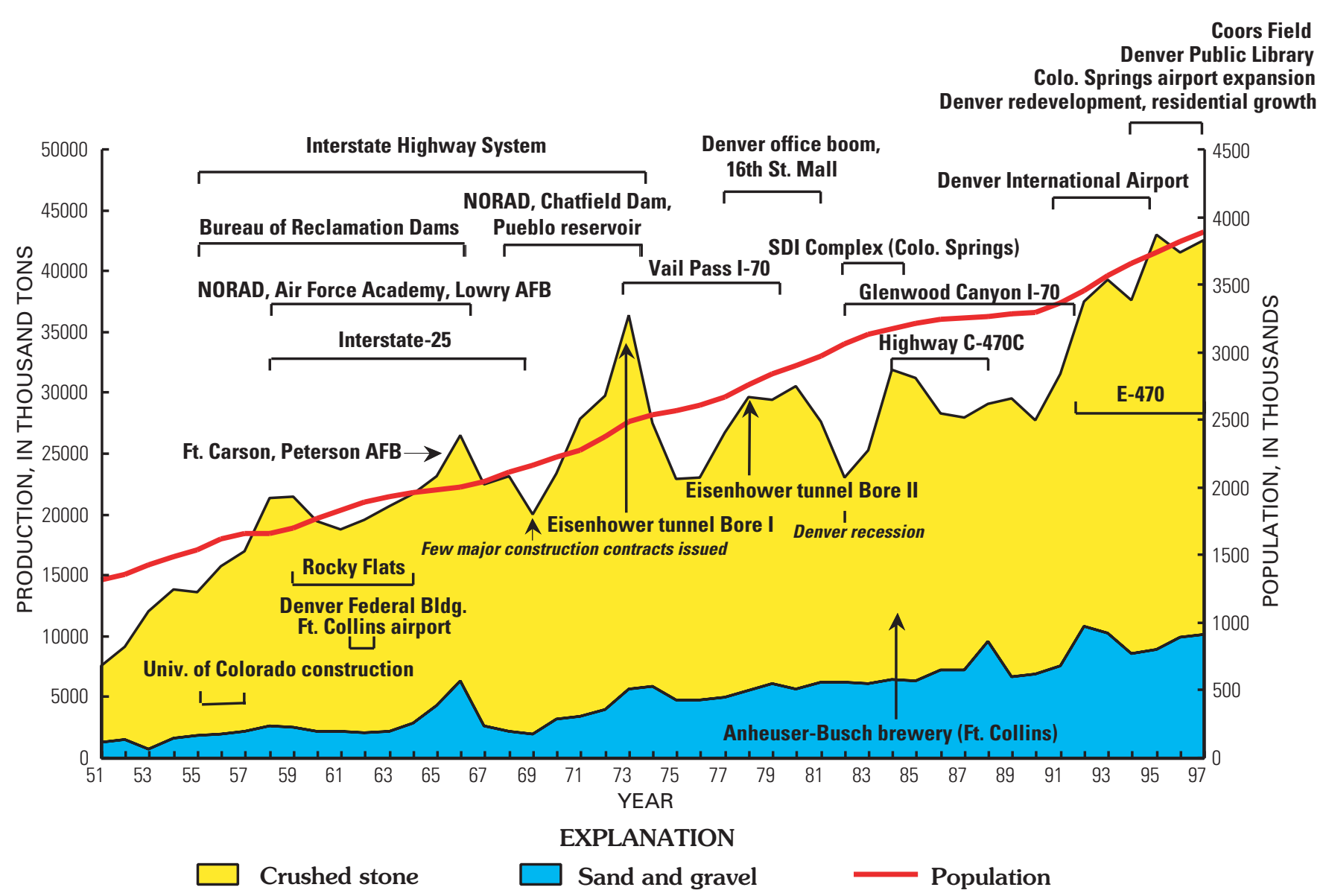

Figure 7. Colorado aggregate production and population growth for 1951 through 1997. 
example, replacement of old warehouses with a new sports complex). Potential sources of recyclable material are widely dispersed, making transportation a major cost of recycling.

Nationally, 68 percent of the aggregate recycled from concrete is used as road base. The remainder is used for new concrete mixes ( 6 percent), new asphalt hot mixes ( 9 percent), highvalue riprap ( 3 percent), low-value products like general fill ( 7 percent), and other uses ( 7 percent). The low usage of aggregate recycled from concrete in new concrete and asphalt hot mixes (15 percent) is related to aggregate quality, both real and perceived. State agencies have been slow to accept recycled aggregate from concrete for high-quality uses such as road surfacing. Specifications from 44 States, however, allow its use as road base material (U.S. Geological Survey, 1999).

Regional recyclers must compete among themselves and with nearby landfills for sporadically available material. The amount of the total available material that can be obtained by a particular recycler depends on three factors: (1) the price the recycler or landfill charges the construction company to accept their debris (tipping fee); (2) relative distances to competing recycling or treatment facilities (hauling costs); and (3) quantity of material available. Typical costs for recycling aggregate in the Denver area were about $\$ 4$ per ton in 1996 (Wilburn and Goonan, 1998).

Recycling of construction materials has grown in response to the demand for aggregate (fig. 8). Recycling has the potential to reduce the amount of waste sent to landfills, to preserve natural resources, and to save energy and other costs, while reducing environmental disturbance associated with mining (U.S. Interagency Working Group on Industrial Ecology, Material and Energy Flows, 1999). Potential sources for recycled material grow as maintenance or replacement of the Nation's infrastructure continues. The cost of sending construction debris to a recycler or to a landfill and the economics of the recycler's processing costs and sale price determine the amount of material ultimately available for recycling. At approximately $\$ 0.13 /$ ton/ kilometer, the cost of transportation has a significant impact on the economics of construction operations. It is not surprising that mobile recycling is becoming common for larger construction projects as a means of avoiding high transportation, disposal, and new material costs.

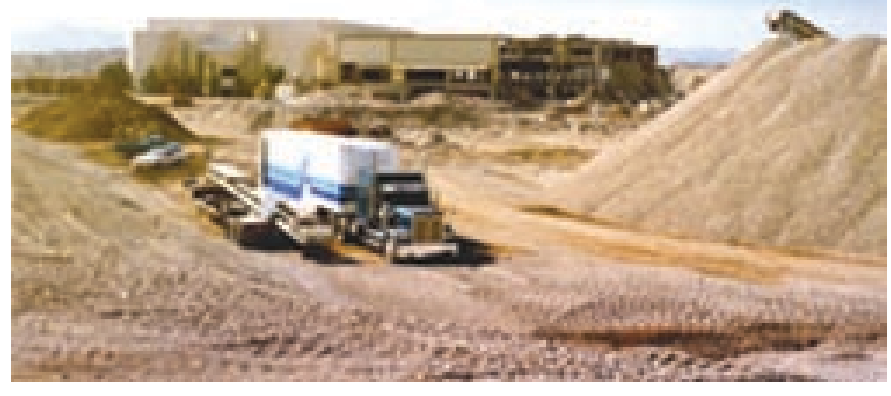

Figure 8. On-site recycling of demolition debris for use as aggregate at the former Cinderella City shopping mall in Denver, Colo.
Estimated production of recycled aggregate in the sixcounty Denver metropolitan area grew from about 1.2 million tons in 1997 to 2.5 million tons in 1998, with a projected 1999 production of about 4 million tons (Russel Hawkins, Allied Recycled Aggregates, oral commun., 1999). Increasingly, large redevelopment construction projects include the recycling of cement and asphalt concrete, increasing both supply and demand of recycled aggregate. Redevelopment of the abandoned Stapleton Airport in Denver alone will generate a total of 6 million tons of recycled cement concrete from demolition of runways and terminal buildings (Carder, 1999).

Adding new recycling capacity to a market with a finite level of feed material impacts the profitability of all recyclers in a given locality. All recyclers must compete for these materials by reducing their charges for accepting debris and the price of their recycled aggregate product. The economic climate for recycling can be improved by making waste disposal in landfills less attractive, increasing markets for recycled materials, increasing research and development to improve recycled aggregate quality, and changing specifications to accept recycled material when it is technically appropriate.

\section{Future Outlook}

The steady increase in aggregate production and use that have occurred in the Front Range urban corridor since the 1950's is expected to continue (fig. 7). Even if large construction projects were to cease, demand for aggregate can be expected to continue at reasonably high levels due to projected population growth and demand for infrastructure improvements and maintenance associated with that growth.

Although the project area has an abundance of aggregate resources, recoverable resources are being hauled from greater distances as local resources become depleted or inaccessible. The tonnage of aggregate being locally permitted for extraction has steadily decreased over time, and the area has been producing more aggregate than it has been permitting new resources since 1994, which is a net decrease in available reserves. If this trend continues, aggregate operators may be forced to move to resource areas even farther away from local markets, resulting in higher transportation costs. Increased costs for this aggregate would be passed along to the State or counties as higher construction bids, to the contractor as higher supply costs, and ultimately to the consumer in the form of higher taxes, user fees, and purchase prices.

Although permitted aggregate resources are sufficient for the short term, they cannot sustain a continued strong demand. The aggregate resource availability concerns expressed by H.B. 1529 are even more pressing today than they were in 1973. Decisions made in the near future will have long-term effects on the continued availability of reasonably priced aggregate in the project area and the entire region.

\section{Energy Resources}

Oil, natural gas, and coal are widely used for fueling motor vehicles, generating electricity, heating homes and businesses, 
and other domestic and commercial purposes. These energy resources occur in Cretaceous rocks exposed along the Front Range mountain front and extending eastward at depth into the western and central part of the Denver Basin (fig. 3) (Kirkham and Ladwig, 1979, 1980). Coal was produced from shallow underground mines in the project area; oil and natural gas are produced from wells drilled to depths of many thousands of feet in the Denver Basin.

Past production of energy resources in the Front Range region occurred principally in rural areas, largely removed from urban centers. However, dramatic urban growth along the Front Range in the last few decades has encroached on regions of past and current energy production. Furthermore, population growth over the next 20 years is expected to be significant, especially in the northern Front Range region, largely within the extent of the project area (Denver Regional Council of Governments, 2000; Colorado Department of Local Affairs, 2000). Consequently, there will probably be increased competition for use of the land surface between surface owners and owners or lessees of the underlying mineral rights. Information on past and probable future energy production potential is important in addressing current land use questions.

\section{Oil and Natural Gas Resources}

Oil and natural gas were first produced along the Front Range of Colorado over 130 years ago. Production has continued to the present and additional resources are available for production well into the future (Carpenter, 1961; Higley and others, 1995). Although drilling for petroleum resources began in 1881, only in the past 30 years have large accumulations of oil and natural gas been discovered in parts of Weld, Adams, Boulder, Larimer, and Denver Counties.

Much of the production occurs within the greater Wattenberg area (fig. 9), a geographic area defined by the Colorado Oil and Gas Conservation Commission for regulatory purposes. A significant part of the greater Wattenberg area falls within the boundaries of the project area, where over 7,000 wells currently produce oil, gas, or both. The potential for future drilling and production is highest in the central and northern parts of the project area.

The greater Wattenberg area, which includes numerous individual oil and natural gas fields, has produced more than 2 trillion cubic feet of gas and more than 245 million barrels of oil (Debra Higley, USGS, written commun., 2001). By comparison, in 1999, total natural gas use in the United States was about 21.4 trillion cubic feet, whereas oil use was about 7.1 billion barrels (EIA, 2001). Nevertheless, accessibility to growing local markets has made the greater Wattenberg area an important energyproducing region. Energy resource production has also provided many jobs for local citizens and tax revenues for State and local governments.

Oil and gas produced in the project area is largely from Cretaceous rocks that range in age from 68 to over 100 million years, although some older rocks also host these resources (fig. 10). Generation of oil in the Cretaceous rocks probably began about 70 million years ago, and gas was generated subsequently

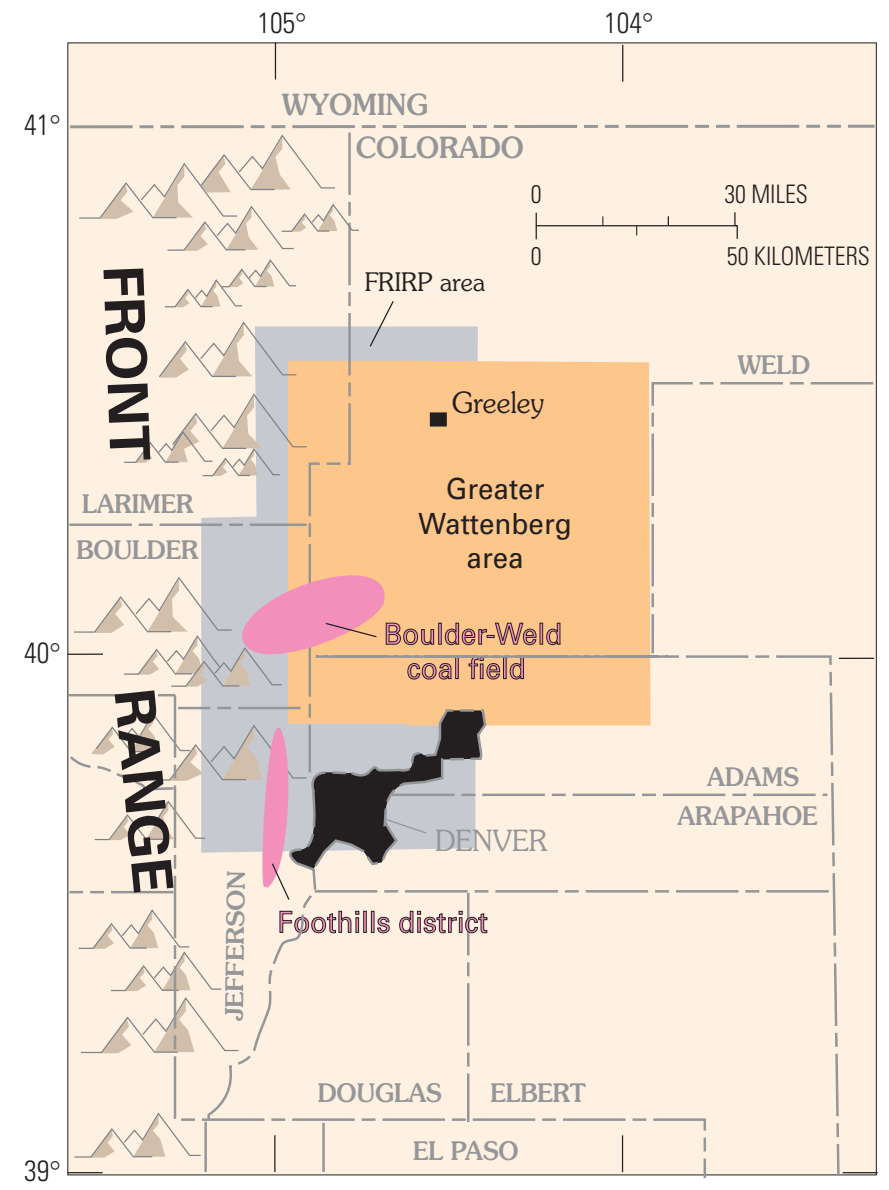

Figure 9. Location of the Wattenberg oil and natural gas producing area and the Boulder-Weld coal field and Foothills district coal producing areas relative to the Front Range Infrastructure Resources Project (FRIRP) area.

(Weimer, 1996). Oil and gas are generated in fine-grained source rocks, primarily shales, that contain large amounts of organic matter. The newly generated oil and gas migrate into nearby reservoir rocks, mostly sandstones that can hold large volumes of petroleum (fig. 11).

Source rocks from which petroleum in the Denver Basin was generated include the Skull Creek, Mowry, Huntsman, and Graneros Shales (fig. 10). Reservoir rocks from which most oil and gas production occurs in the project area include the Muddy ("J") Sandstone (Dakota Group), the "D" sandstone of the Graneros Shale, the Codell Sandstone Member of the Carlile Shale, the Niobrara Formation, and sandstones in the Pierre Shale (Hemborg, 1993a, b, c; Weimer, 1996). Depths to these oil and gas reservoirs generally range from about 4,000 to more than $9,000 \mathrm{ft}$.

\section{Coal Resources}

Coal was first mined in the project area in the early 1860's near the town of Marshall, Colo., in the southwestern part of the Boulder-Weld coal field (fig. 9). Coal mining continued until the last mine in the Boulder-Weld coal field was closed in 1979 


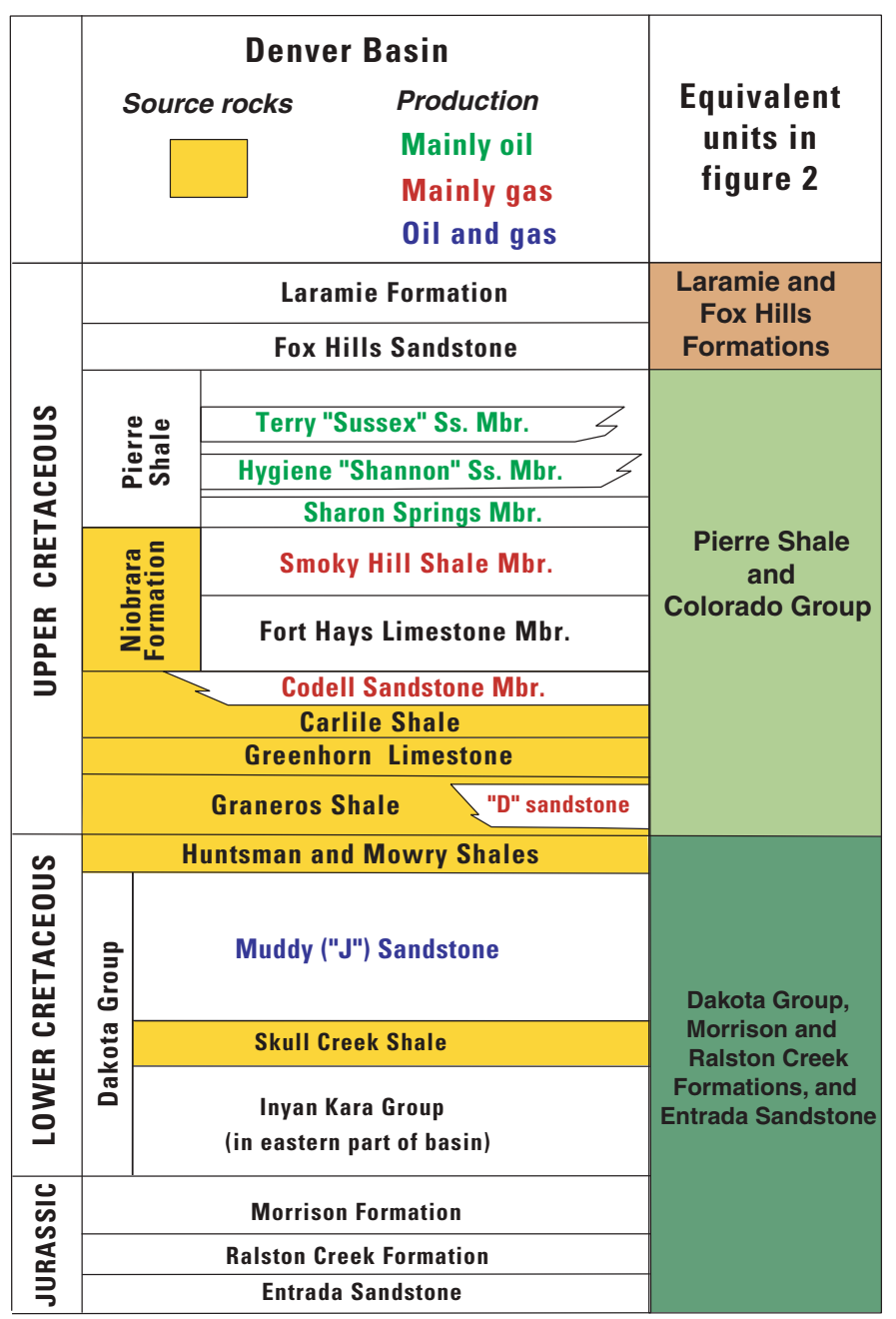

Figure 10. Stratigraphic column of major petroleum source and reservoir rocks in Denver Basin and equivalent units as shown on figure 2. Formations labeled in green primarily produce oil; those labeled in red primarily produce gas. Rocks from which both oil and gas are produced are labeled in blue.
(Kirkham and Ladwig, 1980). Over that time period, coal was also mined in the Foothills district in eastern Jefferson County (fig. 9), as well as in other parts of the Front Range region (Kirkham and Ladwig, 1980). Most of the approximately 107 million short tons of coal mined in the Boulder-Weld coal field were produced from over 130 underground mines (Kirkham and Ladwig, 1980; Tremain and others, 1996). More than 6.6 million short tons of coal were mined in the Foothills district (Kirkham and Ladwig, 1980). By comparison, in 1999, total coal consumption in the United States was about 1.04 billion short tons (EIA, 2000). Nevertheless, local coal was once important for supporting activities related to mining of silver, gold, and other metals in the mountains of the Front Range (Tremain and others, 1996).

Most of the coal produced in the project area is from Cretaceous rocks approximately 70 million years old (Kirkham and Ladwig, 1979, 1980; Weimer, 1996; Roberts and Kirschbaum, 1995). The coal in both the Boulder-Weld and Foothills districts is in the Laramie Formation (fig. 10). The coals have a rank ranging from subbituminous $B$ to subbituminous $C$, and a sulfur content of generally less than 1 percent (Kirkham and Ladwig, 1979). Although lignite occurs in the overlying Denver Formation in parts of the project area, less than 36,000 short tons were mined.

\section{Impact of Energy Production}

Exploration and development of energy resources have both positive and negative impacts on a region. In addition to making their commodities available for Front Range residents, exploration and production industries employ many people in the region. Income from severance taxes collected from the production of energy resources is returned to State and local governments. However, energy resource production may limit other uses of the land surface in the producing area.

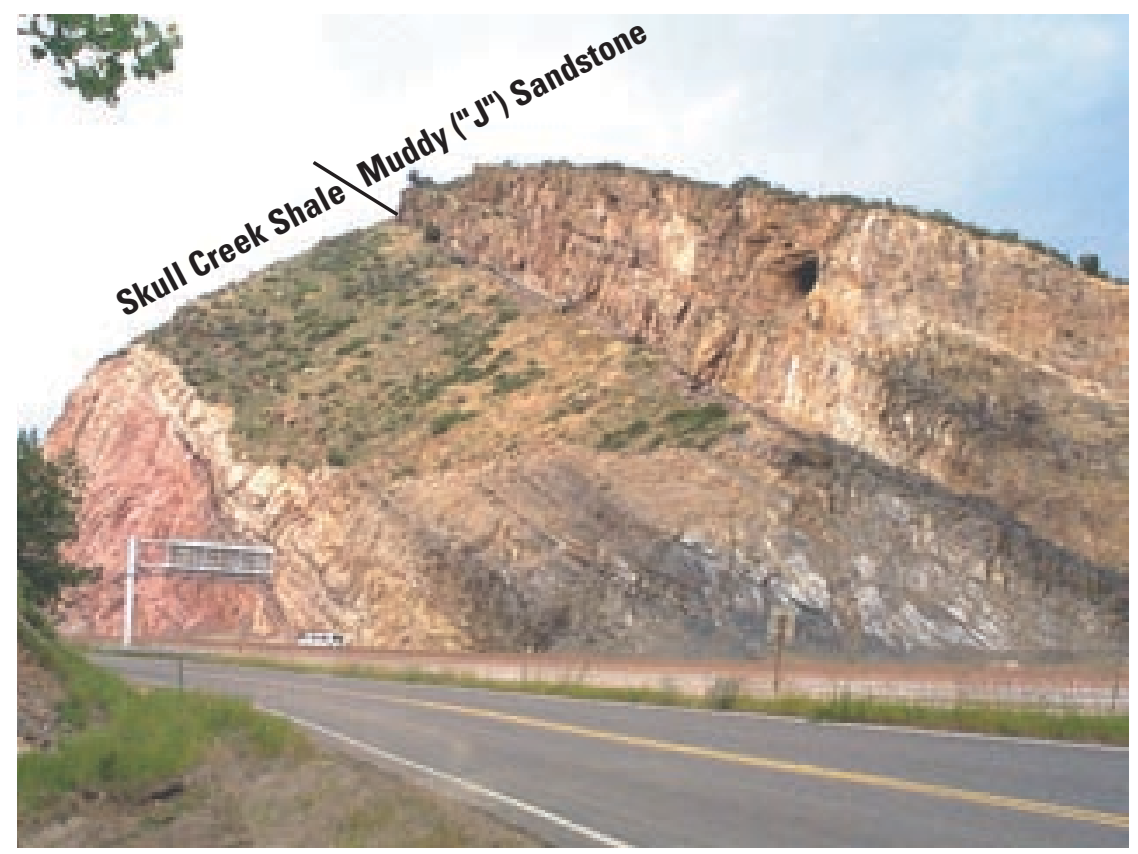

Figure 11. Cretaceous petroleum source (Skull Creek Shale) and reservoir (Muddy ("J") Sandstone) rocks (fig. 10) exposed at the Turkey Creek water gap through the Dakota Hogback along U.S. 2852 mi southeast of Morrison, Colo. Along the mountain front on western edge of project area, Cretaceous rocks dip steeply eastward into the Denver Basin. 


\section{Oil and Gas}

Oil and gas operators, as owners or lessees of the mineral rights, are legally afforded ready access to land surface areas for drilling, development, production, and maintenance of wells, whether or not they own the overlying land surface. Production of oil and natural gas requires (1) roads to access wells and other production equipment, (2) pump jacks and (or) well heads, (3) separators, and (4) storage tanks. This production infrastructure, built during development of individual wells or an entire producing field, stays in place throughout the life of the well or field, which can be decades. While being used for oil and gas production, the land occupied by the production infrastructure may be largely removed from use for other purposes such as agriculture, grazing, and urban and commercial development. The amount of land devoted to oil and gas production is largely a function of the number of wells, their spacing, and the associated infrastructure that it takes to extract the available resources.

The oil and gas production infrastructure associated with the more than 7,000 wells in the project area occupies well over 2,000 acres of land (Fishman and others, 1999). Access roads and associated facilities account for most of this acreage, although a significant area is also devoted to oil well pump jacks, storage tank batteries, and gas wells. Not only does the production infrastructure occupy land, preventing its use for other purposes, but it segments the land surface, which in turn may fragment habitat, agricultural operations, or urban development. In addition, land disturbed by oil and gas operations may provide favorable sites for establishment of invasive plant species that can spread to adjacent areas. Governmental agencies that oversee petroleum production strive to balance the needs of oil and gas operators with the welfare of surface owners, while also following all established rules and regulations.

\section{Coal}

Coal mining ceased in the Front Range region over 20 years ago; however, impacts of past underground mining continue to affect land use, at least locally. Most of the coal produced from the Laramie Formation was mined at shallow depths (less than $50 \mathrm{ft}$ to more than $500 \mathrm{ft}$ ) using the common "room and pillar" mining method (Myers and others, 1975; Roberts and others, 2001). Coal is extracted from "rooms," while "pillars" of coal are left between mined-out rooms to support the mine roof. However, collapse of the overlying rock and soil into the rooms left from coal mining is common. The degree to which the land over collapsing mine roofs may subside, if at all, depends, at least in part, on (1) the dimensions of the rooms, (2) the thickness and physical characteristics of rock and soil above mined areas, and (3) the pillar size. Studies over abandoned mines in the project area found varying degrees of land surface disruption resulting from subsidence, with the effects ranging from welldeveloped collapse pits and ground subsided as much as several feet (fig. 12) to structural damage to overlying buildings (Myers and others, 1975; Hynes, 1984, 1986; Herring and others, 1985; Sherman, 1986; Matheson and Bliss, 1986; Phillips and Holmquist, 1986).

\section{Did You Know.......}

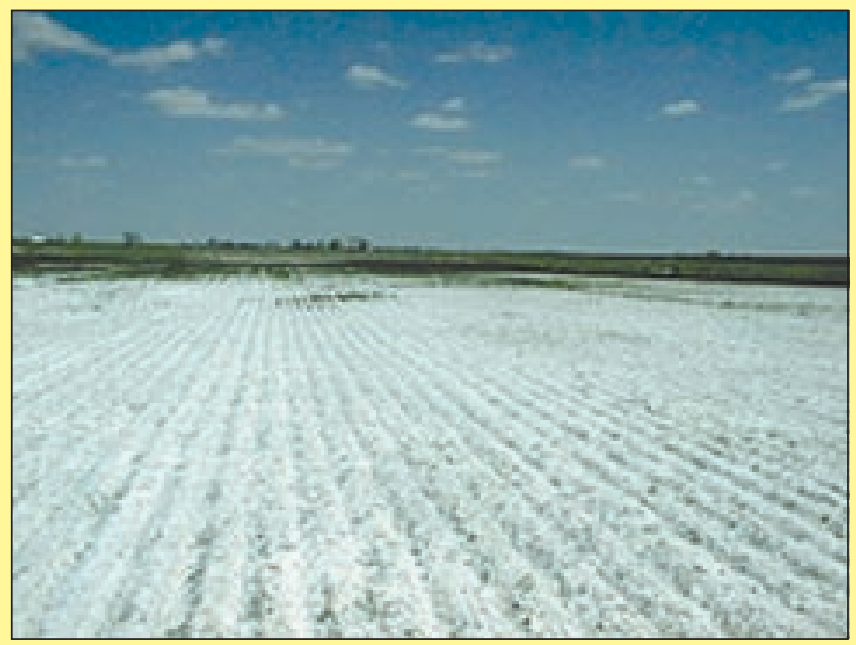

Along Interstate 25 north of Denver are conspicuous patches of white soil, which have been attributed to salt from brine produced during the development of oil wells. However, these alkali salt crusts are natural phenomena related to water movement in soils containing abundant salts probably derived from the underlying rock.

Fires in abandoned coal mines may also affect use of the land overlying the mines. Fires in many abandoned mines in the project area started either spontaneously or were ignited by human activity (Myers and others, 1975; Herring and others, 1985). These fires burn whatever coal remains in the mines, including that in pillars, which can lead to collapse and surface subsidence well after the mines have been abandoned (Myers and others, 1975; Herring and others, 1985). Although this type of subsidence has disrupted the land surface only locally, subsidence may become more regional in scale should still-burning shallow mine fires spread.

As a way to identify potential subsidence hazards, airborne magnetic surveys can be used to detect highly magnetic rock formed as a result of coal-mine fires (Rodriguez, 1983). This technique could be used on a regional scale to map the distribution of magnetic rock that may be associated with mine fires and, consequently, identify areas potentially susceptible to land surface subsidence. A recent magnetic survey of limited areal extent not only detected highly magnetized rock associated with known mine fires, but identified similarly magnetized rock in areas where mine fires were not known to have occurred, at least while the mine was in operation (Fishman and others, 2001). This finding suggests that mine fires may be more widespread than originally believed.

\section{Resource Availability and Future Outlook}

Significant volumes of oil, gas, and coal remain in the rocks of the Denver Basin, but the amount produced in the future depends on a combination of geological, technological, 


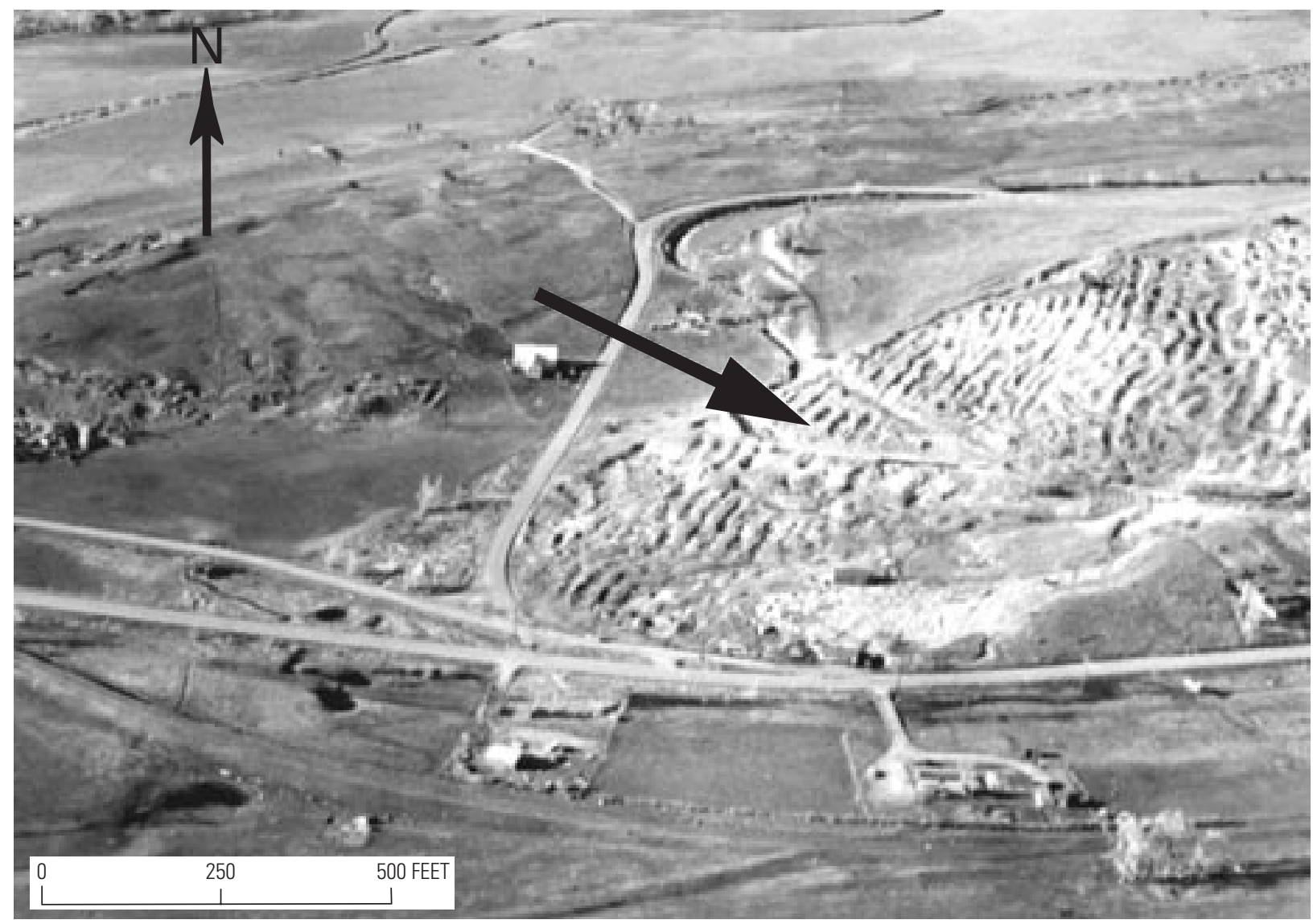

Figure 12. Aerial photograph of ground over coal mine subsidence (arrow). Photograph was taken near southwestern part of Boulder-Weld coal field (fig. 9) south of Boulder, Colo. Morphology of subsided area reflects room (lows) and pillar (ridges) mining method used to extract coal.

environmental, political, and economic factors. A better understanding of the geology of the source and reservoir rocks, as well as the structural and thermal evolution of the Denver Basin, has helped to identify more reserves of oil and gas in the region. Furthermore, advances made in exploration and production technologies have greatly improved the volume of oil and gas that can be recovered. Current estimates for the life of production from wells in the greater Wattenberg area are at least 30 years, and the life of wells could be further lengthened by advancements in production technologies and additions to the reserves from other, as yet untested reservoirs (for example, natural gas from coal beds). Even without the development of new technologies, much of the greater Wattenberg area has a moderate to high potential for additional drilling to exploit remaining oil and gas.

In contrast, future production of coal or lignite within the project area is unlikely. Most of the coal occurs at shallow depths and directly beneath or near urban and commercial centers. The impact of mining on land use and the environment would probably be viewed as unacceptable. In addition, higher quality coal [greater British Thermal Unit (BTU) content] being mined elsewhere in Colorado and in other States makes it unlikely that coal from the Front Range could compete favorably despite its close proximity to potential markets. The value of the coal beds may, instead, rest in their potential for economic concentrations of natural gas as coal-bed methane, rather than for the coal itself (Roberts and Fishman, 2000).

Although oil and gas resources remain in the ground for exploitation, continued growth in the Front Range region may limit future development of additional energy resources and, in fact, may curtail ongoing resource development. Urban expansion in the project area is encroaching on the greater Wattenberg area, putting petroleum production in competition with urbanization for use of the land (fig. 13). Even though oil and gas operators, as owners or lessees of the mineral rights, have legal access to the land surface for exploration and production, State statutes and city and county regulations prevent or limit exploration and production activity where development has already occurred. Thus, some portion of the petroleum resource base has already been excluded from production. Although petroleum production coexists with suburban development in places, some wells in developed areas are being abandoned by producers for various reasons. As more wells are abandoned or new drilling is precluded due to urbanization, the petroleum resource base is artificially diminished, which in turn lowers the volume of petroleum available in the marketplace. This tradeoff must be weighed as land use issues are addressed in this region of rapid growth. 


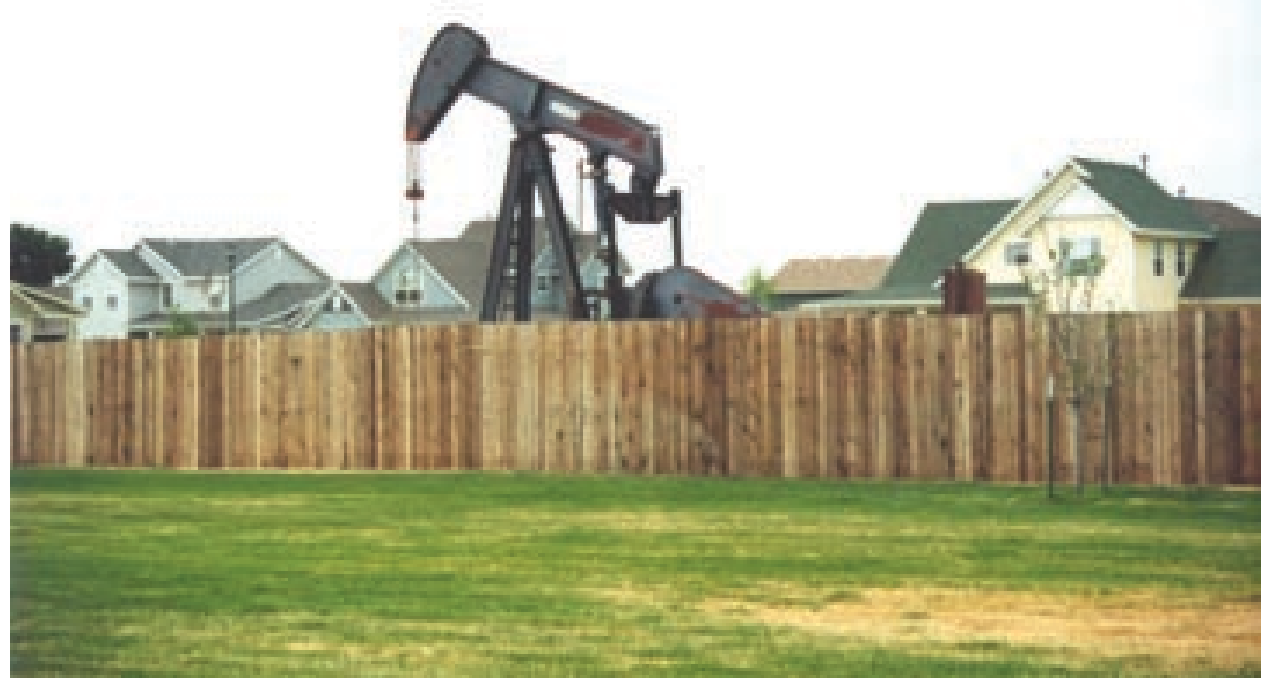

Figure 13. A new residential community north of Denver shares its neighborhood with oil production activity in greater Wattenberg area.

\section{Water Resources}

Urban areas commonly rely on ground water for at least part of their municipal water supply. As population increases, urban areas expand and require larger volumes of water. However, the very same growth that demands more water may ultimately decrease its availability. In addition, human activities in expanding urban areas can introduce ground-water contaminants that degrade its quality, thereby limiting its use. Effective planning and management of ground-water resources are critical for conserving and protecting present ground-water supplies and ensuring their future availability.

\section{Ground-Water Aquifers}

An aquifer is a water-saturated geologic formation, group of formations, or part of a formation that is permeable enough to yield water to wells or springs in economic quantities. Ground water is present in shallow alluvial aquifers and in deeper bedrock aquifers underlying much of the Front Range area in Colorado. In the project area, water from the shallow alluvial aquifers is used primarily for irrigation, whereas water from the bedrock aquifers supplies primarily drinking water (Robson, 1989).

\section{Shallow Aquifers}

Shallow aquifers in the project area occur within all of the geologic units of Quaternary age shown in figure 2, but the primary water-bearing units are the floodplain alluvium and low terrace gravel unit and the intermediate terrace gravel unit, which correspond to major stream valley deposits. Geologic units of Quaternary age occur as a mantle of unconsolidated sediments overlying older, more consolidated bedrock and have a permeability that generally is $200-300$ times larger than the average permeability of the bedrock. Because the unconsolidated sediments generally are much more permeable than the bedrock, water that infiltrates the ground from the land surface accumulates in the pore spaces of the unconsolidated sediments on top of the bedrock surface, forming shallow aquifers (fig. 14).

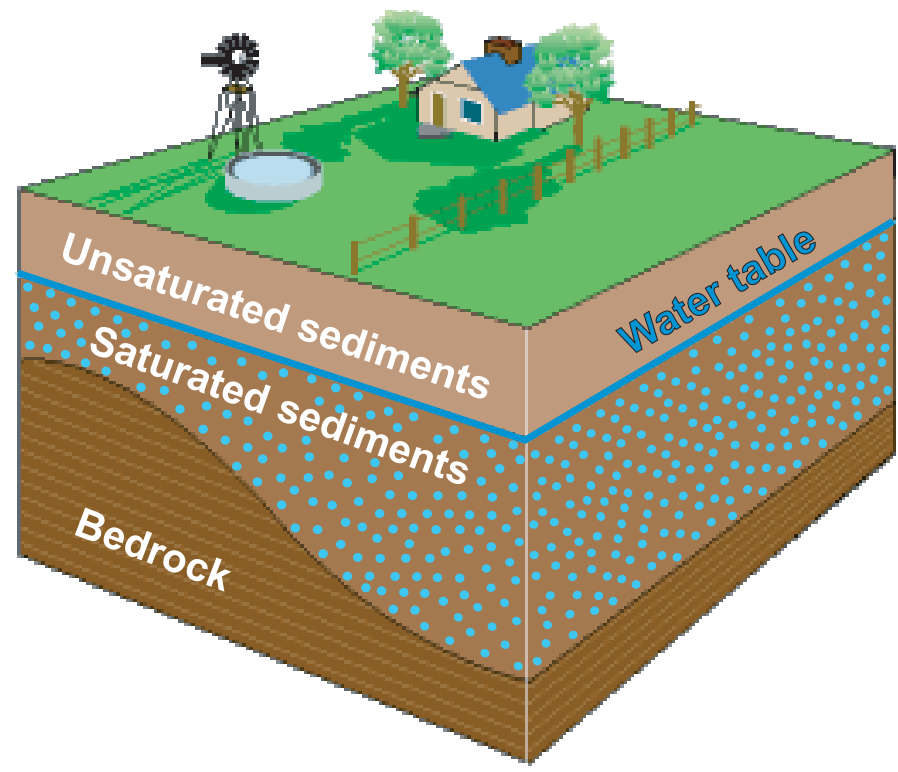

Figure 14. Distribution of water in unconsolidated sediments of a shallow aquifer deposited on impermeable bedrock. Water table marks top of saturated zone in which pore spaces in unconsolidated sediments are filled with water. 
The unconsolidated sediments that contain shallow aquifers range in thickness from less than $20 \mathrm{ft}$ in upland areas between stream valleys (high terrace and pediment gravels and eolian deposits) to more than $100 \mathrm{ft}$ in the floodplain alluvium and low terrace gravels of principal stream valleys (Robson, 1996; Robson, Arnold, and Heiny, 2000a, b; Robson, Heiny, and Arnold, 2000a, b). In some places, thick unconsolidated sediments (60-100 ft) occur in long, linear trends outside of principal stream valleys (fig. 15). These unusual deposits appear to mark the location of ancient stream valleys (paleovalleys) formed by the predecessors of present-day streams.

Saturated thickness of the unconsolidated sediments (that part of the sediments that has pore spaces completely filled with

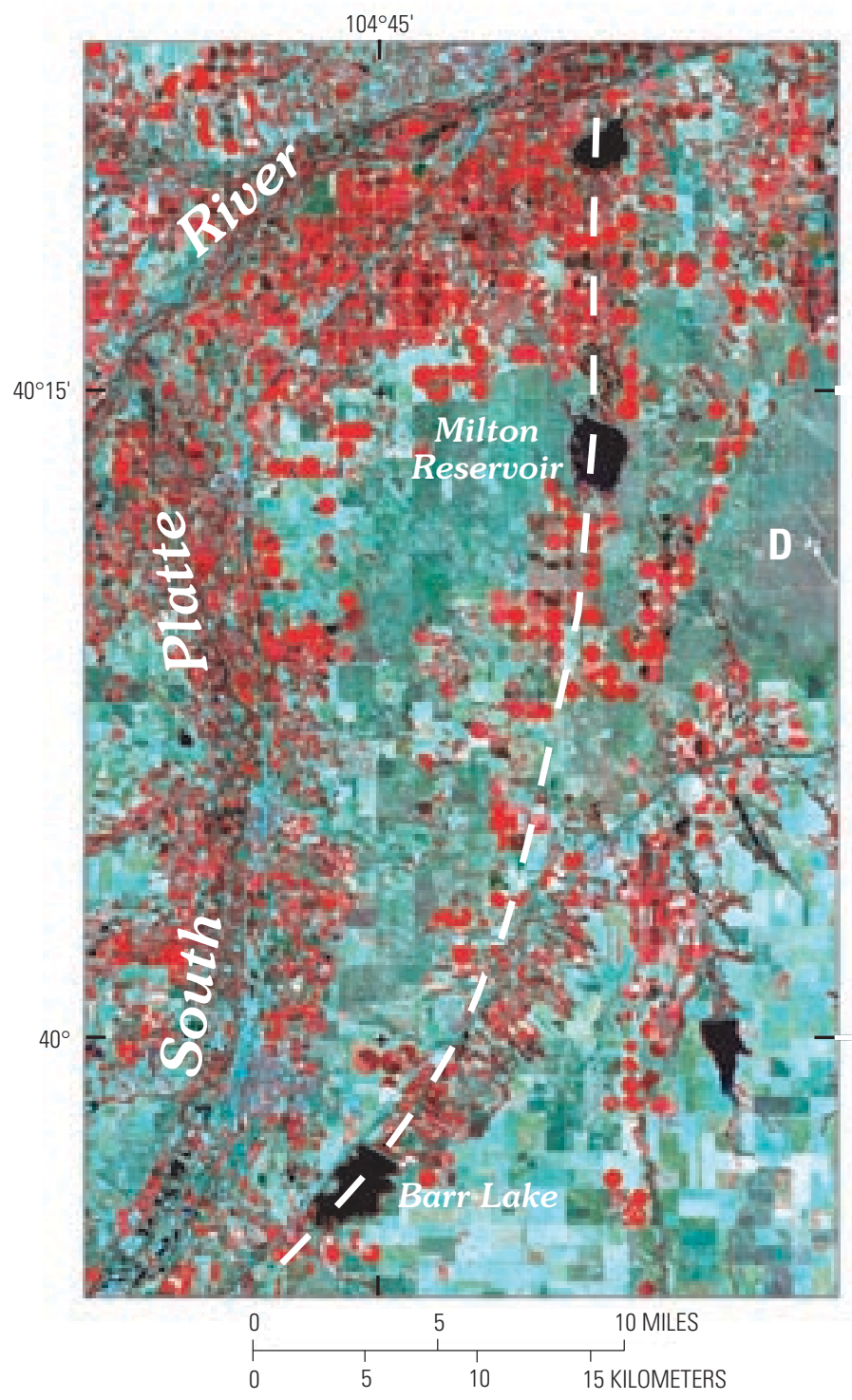

Figure 15. Landsat Thematic Mapper image showing approximate center of ancestral South Platte River paleovalley (dashed line) east of present course of river (Robson, 1996). Paleovalley is marked by high terrace and pediment gravels (see fig. 2) extending northeastward from Barr Lake. Red areas contain healthy broadleaf vegetation. Circular, center-pivot irrigated fields along trend of paleovalley obtain water from wells in paleovalley deposits. Regularly spaced small white dots near $D$ (middle right) and elsewhere are drill pads associated with petroleum production in Wattenberg area. water) ranges from zero in upland areas, where the shallow aquifers may be thin or discontinuous, to between 80 and $120 \mathrm{ft}$ in the thickest sections of stream valleys and paleovalleys. The top of the zone of saturation is called the water table. The water table of the shallow aquifers in the project area is commonly less than $20 \mathrm{ft}$ below the land surface, although it is more than $40 \mathrm{ft}$ deep in some places. Because the shallow aquifers are highly permeable and close to the land surface, they are easily recharged by water from precipitation, irrigation, streams, canals, and ponds. The water table of the shallow aquifers is often higher near the margins of stream valleys than it is near the middle because of the addition of irrigation water from nearby fields (Robson and Heiny, 1998). Conversely, streams flowing along the valleys often drain water from the nearby shallow aquifers, lowering their water tables.

\section{Bedrock Aquifers}

Bedrock aquifers in the project area occur within the Fox Hills, Laramie, Arapahoe, Denver, and Dawson Formations of the Denver Basin. These formations contain four water-bearing units: the Laramie-Fox Hills, Arapahoe, Denver, and Dawson aquifers (Robson and others, 1998). The Arapahoe, Denver, and Dawson aquifers are each contained within their corresponding formations. The Laramie-Fox Hills aquifer includes major sandstones in the lower part of the Laramie Formation, all of the Fox Hills Formation, and, locally, the upper part of the Pierre Shale (fig. 16).

Each aquifer ranges in thickness from $400 \mathrm{ft}$ or more in the central part of the Denver Basin to zero at the western margin near the mountain front where the aquifers crop out at the land surface. In the central part of the basin, water in the LaramieFox Hills, Arapahoe, and Denver aquifers is confined by layers of low-permeability mudstone and shale that lie between the aquifers and impede flow between the aquifers. These confined conditions (also referred to as artesian conditions) create enough pressure in the aquifers to cause the water level in wells (potentiometric surface) to rise above the top of the aquifers (fig. 17). Near the margins of the basin, however, the Laramie-Fox Hills, Arapahoe, and Denver aquifers are unconfined because the overlying formations have been removed by erosion. In these areas, water levels in the aquifers are in equilibrium with atmospheric pressure in a manner similar to the water table in the shallow aquifers. Because the Dawson aquifer occurs within the youngest bedrock formation in the Denver Basin (Dawson Formation), it is nowhere overlain by a confining layer and is unconfined at the top. However, water in the deeper parts of the Dawson aquifer generally is confined by small, discontinuous impermeable layers within the Dawson Formation itself.

Because the bedrock aquifers extend deeper into the Denver Basin and are less permeable than the shallow aquifers, they are more difficult to recharge. In the deeper parts of the basin, recharge must occur through thick sequences of low-permeability sedimentary rocks, which limits the recharge rate. Therefore, it is important to know where the bedrock aquifers crop out at the land surface because it is only in these areas that the aquifers recharge directly from precipitation and surface water. 


\begin{tabular}{|c|c|c|c|c|c|}
\hline \multicolumn{2}{|c|}{$\begin{array}{l}\text { Geologic } \\
\text { unit }\end{array}$} & Lithology & $\begin{array}{c}\text { Geohydrologic } \\
\text { unit }\end{array}$ & $\begin{array}{c}\text { Thickness } \\
\text { (ft) }\end{array}$ & $\begin{array}{c}\text { Water yield } \\
\text { (Gallons per minute) }\end{array}$ \\
\hline \multicolumn{2}{|c|}{$\begin{array}{l}\text { Dawson } \\
\text { Formation }\end{array}$} & $\begin{array}{l}\text { Sandstone and conglomeratic } \\
\text { sandstone with interbedded } \\
\text { siltstone and shale. }\end{array}$ & Dawson aquifer & $0-400$ & $\begin{array}{l}\text { In areas of good permeability } \\
\text { wells, as much as } 200 \mathrm{gpm} \text {. }\end{array}$ \\
\hline \multicolumn{2}{|c|}{$\begin{array}{l}\text { Denver } \\
\text { Formation }\end{array}$} & $\begin{array}{l}\text { Shale, silty claystone, and } \\
\text { interbedded sandstone and } \\
\text { shale. }\end{array}$ & Denver aquifer & $0-500$ & $\begin{array}{l}\text { Can yield } 300 \text { gpm. } \\
\text { Commonly } 150-200 \text { gpm. }\end{array}$ \\
\hline \multicolumn{2}{|c|}{$\begin{array}{l}\text { Arapahoe } \\
\text { Formation }\end{array}$} & $\begin{array}{l}\text { Sandstone and conglomeratic } \\
\text { sandstone with interbedded } \\
\text { siltstone and shale. }\end{array}$ & Arapahoe aquifer & $0-600$ & $\begin{array}{l}\text { Most permeable and heavily } \\
\text { used aquifer in Denver Basin. } \\
\text { Commonly } 750-1,000 \text { gpm. }\end{array}$ \\
\hline \multirow{2}{*}{ 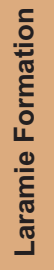 } & Upper & $\begin{array}{l}\text { Shale with interbedded } \\
\text { siltstone and very fine grained } \\
\text { sandstone. }\end{array}$ & $\begin{array}{l}\text { Laramie } \\
\text { confining layer }\end{array}$ & $0-400$ & Yield 2-8 gpm. \\
\hline & Lower & $\begin{array}{l}\text { Sandstone and siltstone } \\
\text { with interbedded shale. }\end{array}$ & \multirow{3}{*}{$\begin{array}{l}\text { Laramie-Fox Hills } \\
\text { aquifer }\end{array}$} & \multirow{3}{*}{$0-400$} & \multirow{3}{*}{$\begin{array}{l}\text { May yield } 150 \text { gpm or more. } \\
\text { Yields less than } 75 \text { gpm are } \\
\text { common. }\end{array}$} \\
\hline \multicolumn{2}{|c|}{$\begin{array}{l}\text { Fox Hills } \\
\text { Sandstone }\end{array}$} & $\begin{array}{l}\text { Sandstone with some } \\
\text { thin shale beds. }\end{array}$ & & & \\
\hline & $\begin{array}{l}\text { ansition } \\
\text { zone } \\
\text { lember }\end{array}$ & $\begin{array}{l}\text { Sandstone, shale, and } \\
\text { siltstone. }\end{array}$ & & & \\
\hline \multicolumn{2}{|c|}{ Pierre Shale } & $\begin{array}{l}\text { Shale with interbedded } \\
\text { fine-grained sandstone. }\end{array}$ & $\begin{array}{c}\text { Pierre } \\
\text { confining layer }\end{array}$ & $0-8,000$ & $\begin{array}{l}\text { Yields of 5-7 gpm from thin } \\
\text { sandstone units. }\end{array}$ \\
\hline
\end{tabular}

Figure 16. Geohydrologic characteristics of bedrock aquifers in project area. Geologic units are color coded as they appear on figure 2 .

Similarly, it is important to know where bedrock aquifers are in direct contact with shallow aquifers in principal stream valleys because it is in these areas that flow is greatest between the two. Water flows from the bedrock aquifer to the shallow aquifer when the water level in the bedrock aquifer is higher than the water level in the shallow aquifer. Conversely, water flows from the shallow aquifer into the bedrock aquifer when the water level is higher in the shallow aquifer. In the project area, ground

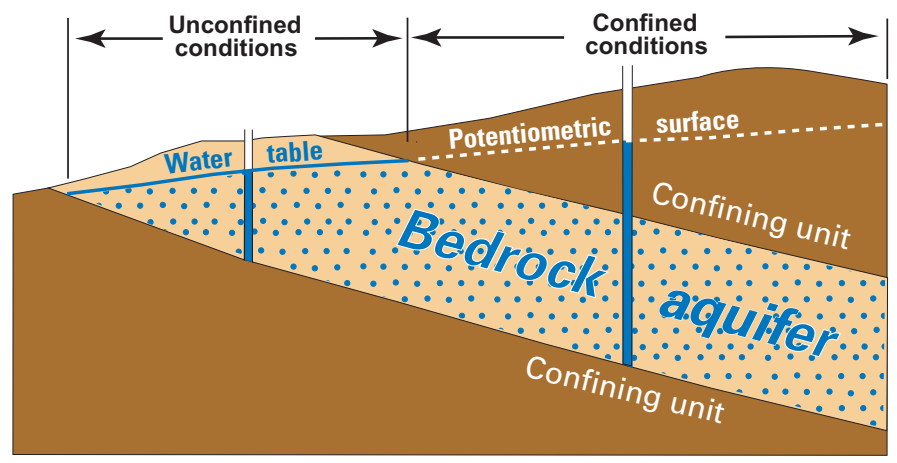

Figure 17. Confined conditions exist in deeper parts of Denver Basin where bedrock aquifers are overlain by confining layers. Unconfined conditions exist near margins of basin where bedrock aquifers crop out at land surface. Potentiometric surface marks the level to which water rises in wells in confined aquifer due to water pressure (modified from Robson and Banta, 1995). water generally flows from the shallow aquifers to the bedrock aquifers in upland areas between stream valleys and from bedrock aquifers to shallow aquifers along the margins of stream valleys (Robson and Heiny, 1998).

\section{Resource Development and Use}

Approximately 48,500 permits are on file with the Colorado Division of Water Resources for wells drilled into shallow and bedrock aquifers in the Colorado Front Range area between Colorado Springs and Fort Collins (Glenn Graham, oral commun., 2001). Wells drilled into the shallow and bedrock aquifers of the project area supply water for drinking, irrigation, livestock, and industrial and commercial uses. Many of these wells are also used to monitor water levels and are sampled for water quality analyses.

Shallow aquifers in the project area are easily recharged, so water levels generally have not been greatly affected by the development of urban areas. Water levels decline and rise from year to year due to climatic fluctuations and changes in withdrawal rates, but long-term average water levels do not change significantly in spite of increased development.

In contrast, water levels in the bedrock aquifers are more sensitive to increases in urban development because they are less permeable and have limited outcrop areas where they can 


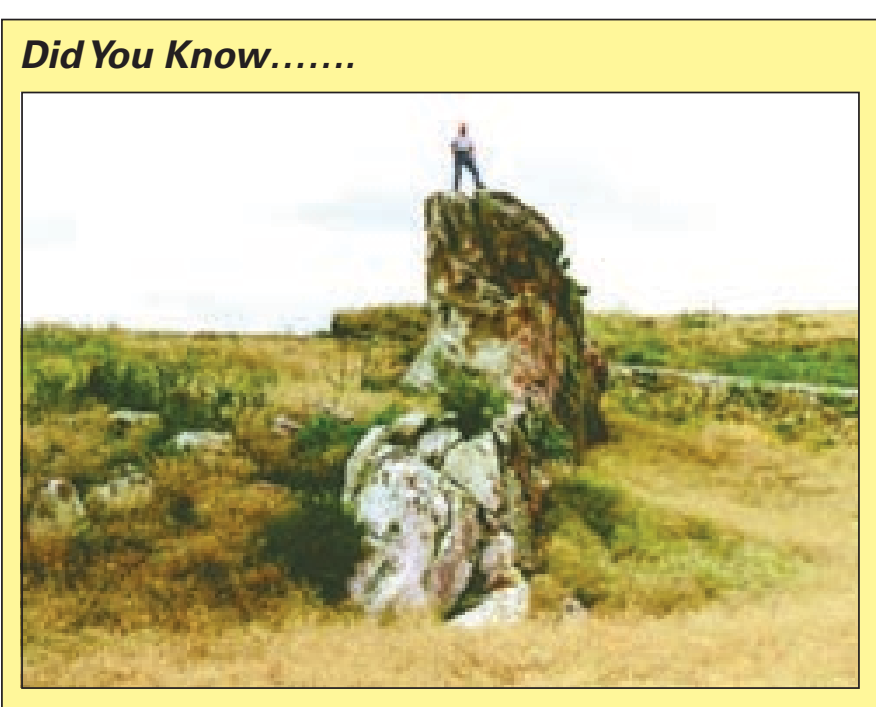

Near the mountain front the sedimentary rocks, including the bedrock aquifers, are steeply tilted to vertical. In this area, the aquifers are exposed over relatively narrow areas that can easily be blocked from surface water recharge even by very modest-scale construction projects such as homes, parking lots, and roads.

receive recharge from precipitation and surface water. Increases in impermeable surfaces associated with urban development (for example, streets, parking lots, and buildings) can significantly decrease the area of aquifer outcrops and reduce recharge.

Unlike the water levels in the shallow aquifers, some wells in the bedrock aquifers of the Denver Basin have recorded drawdowns of more than $250 \mathrm{ft}$ between 1991 and 2000 (Colorado Department of Natural Resources, 2000). Although these drawdowns are significant and expensive to well owners because they must lower the pumps in their wells, they do not represent a proportionate decrease in the amount of water available in the aquifers. Because the water in these wells is under artesian pressure, water is pushed up the wells far above the top of the aquifers. The dramatic decrease in well water levels is more the result of lowering the water pressure in the aquifers rather than actually de-watering the pore spaces of the aquifers. In spite of large drawdowns, the water level in the wells is still above the top of the aquifers. Thus, the aquifers still contain a large volume of water, but because they are very slow to recharge (perhaps taking thousands of years), water that is withdrawn from the aquifers may be, in effect, nonrenewable by natural means.

The same characteristics (that is, shallow depths and generally high permeability) that allow easy recharge of the shallow aquifers cause them to be particularly susceptible to contamination from the land surface. Pollution from sources such as underground fuel storage tanks, chemical spills, landfills, and fertilizers and pesticides applied to crops and lawns can easily infiltrate shallow aquifers and can degrade the quality of their water. Thus, although water in the shallow aquifers is easily renewable, it may not be suitable for some uses. Studies (Dennehy and others, 1995) have shown that water quality in shallow aquifers can be affected by a number of factors including land use, depth to the water table, and the rate and direction of ground-water movement. It is important to consider these factors when planning for development.
Conversely, the same characteristics that limit recharge to the bedrock aquifers (that is, small outcrop areas, greater depths, and lower permeability) serve to protect them from contamination by surface sources. Because recharging water must infiltrate through thick sequences of low-permeability sedimentary rocks, water carrying pollution from the land surface is slow to reach the aquifers except in outcrop areas. Even in these areas contamination has tended not to travel far from the source during historical times (Robson, 1989).

The shallow depth to water, high well yields, and potentially degraded water quality of the shallow aquifers makes them a suitable source of water for crop irrigation, which requires large volumes of water that can be pumped at a relatively low cost. The greater depth to water, commonly lower well yields, and generally better water quality make the bedrock aquifers a suitable source of drinking water. Smaller volumes of drinking water are required and it is economically viable to pay the higher cost of pumping from the deep bedrock aquifers.

\section{Future Outlook}

As the population of the Front Range urban corridor continues to grow, it will place more demands on the ground-water resources of the area, making the need to properly manage these resources increasingly important. Because surface water and shallow ground water generally have long been appropriated by older communities, many newer communities are turning to the bedrock aquifers of the Denver Basin to meet at least part of their water needs. As water in the bedrock aquifers is limited and the aquifers are slow to recharge, indiscriminate pumping ultimately can deplete them. For this reason, measures need to be taken to conserve, re-use, and replace water withdrawn from the bedrock aquifers.

Implementing practices such as planting native species of grass and other vegetation that require less water (xeriscape), installing water-efficient appliances and plumbing fixtures, and repairing leaky pipes and faucets will help conserve domestic water supplies. Improving the efficiency of irrigation practices may conserve water used for agriculture. Water that has been used initially for drinking or household use can be re-used to water outdoor areas, which allows much of the water to seep back into the ground as recharge. In addition to conserving and re-using water, programs are being developed to artificially recharge the bedrock aquifers by injecting water down wells. Water used for this is taken from surplus stream flow during periods when demand is low. Bedrock aquifers have an advantage over surface storage reservoirs because they lose less water to evaporation and the quality of the water may be better protected. Although the method is still somewhat experimental, such "conjunctive use" projects may prove to be the key to future ground-water resources management in the Colorado Front Range area.

\section{Factors in Resource Availability}

Many factors affect the availability not only of infrastructure resources like aggregate, energy, and water, but also of all 
other natural resources including the land itself. Overall, there is a general lack of awareness that access to resources will be the source of some of the most intense conflicts of the future. Most people take for granted that when they want to repave a road, add an addition to their home, water their lawn, or hike in the local open space, the resources that make it possible will always be there at a reasonable price. That may no longer be the case in the near future. In fact, not too long ago the construction boom along the Front Range produced a shortage in the raw materials needed to make concrete, an incident that went largely unnoticed except by people whose home improvements were put on hold for several months while the needs of commercial customers were met.

However, factors affecting resource availability are not as simple as whether or not a resource is physically available. Various political, economic, and social issues can affect a resource's availability. As urban areas expand, planners and policy-makers must balance multiple, often conflicting demands being placed on the land. A local change in land use in one city can have ripple affects throughout the larger region. As urban density increases and spreads across a region, so does interdependence on the entire region for resources.

Most natural resources are limited by the geography of their location. Co-location conflicts of resource availability have always existed, although typically ignored by all but the parties directly involved because alternatives seemed plentiful. Today, however, competition for land and growing demand for infrastructure resources are creating challenging questions whose answers will have long-range, largely irreversible effects on the economic and social fabric of the region.

\section{Resource Conflicts}

A resource conflict can occur when two or more resources exist within the same geographic area. The conflict arises when there are differences of opinion as to whether resources should be developed at all, which resource should be developed first, or how development of one resource affects the development of another. Resources can be any kind-infrastructure (aggregate, energy, water), biological, agricultural, minerals, scenic, historical, and so forth. For example, consider this scenario, a common one along the South Platte River north of Denver. A very productive truck farm, a local source of fresh vegetables for the Denver metro area, is operating on the lower terrace along the river. Immediately beneath the fertile topsoil lies a deposit of highquality gravel and sand nearly $30 \mathrm{ft}$ thick, suitable for concrete aggregate. The farm obtains water for irrigation and drinking from wells drilled into the gravel deposit (shallow aquifer). Several thousand feet below the gravel deposit the bedrock contains accumulations of oil and natural gas that would be economical to produce. Because of its proximity to a major highway and to Denver itself, this land is considered ideal for commercial or residential development, but a recreation district would like to purchase the land for a multiuse recreational facility.
What would be the best use of the land? This type of question is frequently before city, county, and State officials, and the answers are never easy. The farmer, the aggregate and energy producers, the water board, the local residents, and the developers all have their own opinions and interests. A resource conflict exists. In addition, zoning and existing longrange plans may create another conflict and mineral rights and other legal issues must be recognized, which may further complicate the situation. Selection of a single use from the various possibilities would be to the detriment of each of the remaining interests; no matter which use prevails, resources are lost to society. One logical approach might be to plan a sequence of uses that satisfies the greatest number of interests. For example, aggregate could first be extracted and the pit could be turned into a permanent water storage facility with waterfront property for homes. Of course, agricultural and energy production potential might be lost, as well as the public recreational facility. Alternatively, the truck farm could be continued with oil and (or) gas wells on the property strategically placed to minimize their impact on the ongoing farming, with aggregate resource extraction and development potential delayed for a period of time. There are many other possible resolutions to the question, but the fact remains that no matter how the question is resolved some parties will be dissatisfied and some resources will be lost.

There is no guarantee that there will be a concerted effort to find the best long-term land use scenario. Politics and economics may drive short-term solutions for conflicts that would be better addressed with a long-term view.

A strong economy and its accompanying population increase create a high demand for land for residential and nearby commercial development. As property values and taxes rise, farmers, ranchers, and other private property owners are finding it increasingly difficult to resist selling their land for future development. Valuable resources on the land may be lost forever through resource sterilization.

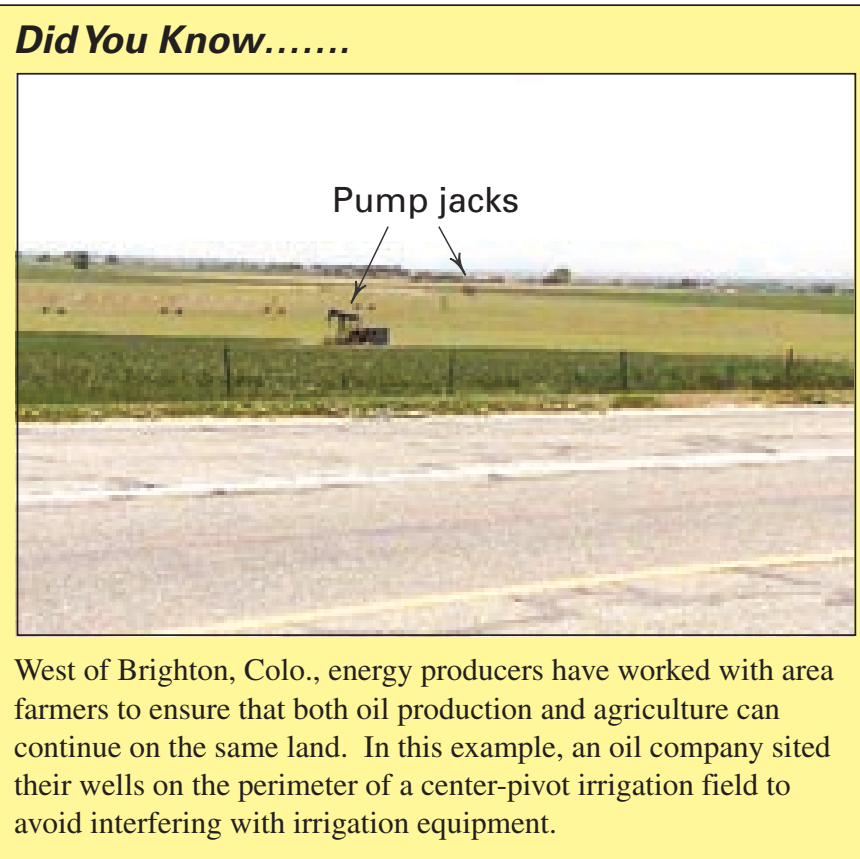




\section{Resource Sterilization}

Resource sterilization occurs when the development of resources is precluded by either an existing land use or the development of another resource. For example, a housing development or shopping center prevents extraction of the gravel underneath. An issue for many years, sterilization of aggregate resources in the project area threatens to become an increasingly important factor as growth and development expand north of Denver.

Beginning in the 1920's, gravel extracted from Clear Creek valley supported the growth of Denver and its west suburbs. Ironically, that growth and its accompanying infrastructure encroached on a 2-mi-long segment of Clear Creek valley before the gravels could be extracted, thereby sterilizing those convenient, high-quality resources from future development (Belinda Arbogast, USGS, written commun., 2001).

Resources can be sterilized in much more subtle ways. Bedrock aquifers at depth in the central part of the Denver Basin area are replenished (recharged) directly by precipitation and surface water where the aquifers are exposed along the margins of the basin. Roads, parking lots, and other impervious surfaces may sterilize aquifer recharge areas, ultimately reducing the amount of water available in wells many miles away. The consequences of this sterilization are extremely long term and are unlikely to be noticed for many generations.

Oil and gas production can also sterilize other natural resources. Parts of the greater Wattenberg area overlap areas containing near-surface aggregate deposits (Schwochow and others, 1974a, b). Colorado statute does not allow aggregate operators to mine immediately adjacent to man-made structures such as oil and gas well sites, access roads, pipelines, and tank batteries. The operator is required to leave a buffer of undisturbed land around these structures, thus eliminating the extraction of some of the available aggregate resource. In fact, in some instances more than 300,000 tons of aggregate may remain in the ground due to the presence of a single well along with its associated production infrastructure (Neil Fishman, USGS, written commun., 2001). Unless wells are abandoned prior to or during aggregate mining, the aggregate resource around them will likely never be mined.

North of Denver, residential development is occurring in an active oil and gas producing area. The developer and the residents own the surface rights, whereas the mineral rights are commonly owned or leased by energy-producing companies. Consequently, the residential community shares its land with oil pump jacks, storage tank batteries, pipelines, gas wells, and access roads. Even with the relatively high cost of oil and natural gas in the year 2001, wells are being purchased, plugged, and abandoned to enhance the residential environment and encourage buyers (fig. 18). The result, of course, is the removal of oil and natural gas resources from the current market, precluding future production in the area. The existing petroleum resources have been sterilized.

\section{Permitting and Mineral/Water Rights}

The process of obtaining permits to extract resources exerts a strong influence on development and availability of all kinds of resources in the project area. During the permitting process, the public has a strong voice in whether resources can be extracted and in the limitations and constraints under which extraction is allowed. However, the ownership of mineral and water rights also has a big impact, and the public is distinctly limited in its input on how owners exercise their legal rights, including sale of their rights to new owners.

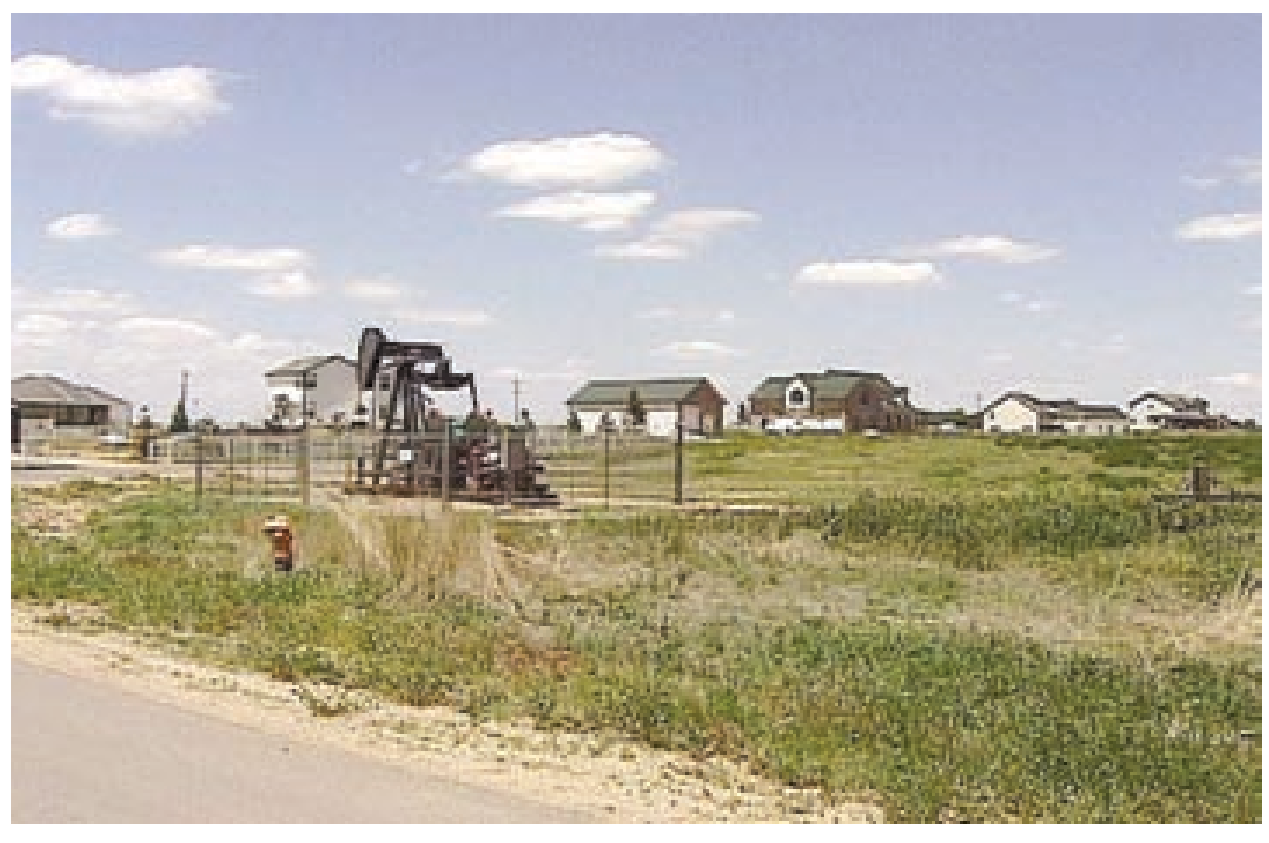

Figure 18. An established oil well pump jack in an actively developing residential area. Regulations limit how close new housing can be built to the pump jack. Even though this well might be purchased, plugged, and abandoned, developers still must design around the well for safety reasons. 


\section{The Permitting Process}

A reclamation plan, permit, and financial performance warranties (with certain exceptions) are required by the State of Colorado for the life of a mine. It is important to note, however, that the State does not grant permission to mine. The Colorado Division of Minerals and Geology issues reclamation permits and ensures that mining and reclamation are completed according to the approved plan submitted by the operator, but local governments grant permission to mine. Thus, the mining operator is responsible for assuring that the mining operation and post-mining land use comply with local land use regulations as well as any master plan for extraction. Additional stipulations to address citizen concerns may result from public participation during the local permitting process.

Permitting and regulation of noncoal mining vary greatly from city to county according to hundreds of zoning and land use regulations. Although the State enacted regulations affecting surface mining, including the Colorado Mined Land Reclamation Act (State of Colorado, 1993) and Colorado Land Reclamation Act for the Extraction of Construction Materials (State of Colorado, 1995), it is local governments that most directly determine how land will be used.

Nearly all of the regional and local issues surrounding mining have social and environmental limits imposed by State and (or) county requirements and standards. Natural resources, such as air, water, wildlife, and vegetation, are subject to preservation and conservation efforts by Federal and State agencies. Human resource issues such as health and safety are addressed under Federal and local planning efforts. Noise, traffic, visual impact, control of land use, and regulation of utilities are operational issues usually controlled by zoning. These issues are viewed as of more importance to the local community than reclamation or environmental degradation itself (National Academy of Sciences, 1980). However, the negative visual impact of a mine generates tremendous emotional citizen opposition rarely dealt with in a quantifiable methodology. In the project area, Jefferson and Boulder Counties attempt to examine site suitability, including the visual impact of a mining operation upon unique landscapes such as hogback ridges, valleys, and scenic and geologic features. These factors may become even more important in the future permitting process.

Multiple levels of government, a lack of binding and coordinated master plans and penalties, and a conflict between the desire for a robust economy and restrictions on urban growth have led to fractured planning policies, including those for resource conservation (Arbogast, in press). In Colorado, the legal power and influence over mining and reclamation have shifted from local to State and Federal agencies and back again. This instability is a detriment to long-term planning for the conservation and development of infrastructure resources.

\section{Mineral Rights}

Declaration of ownership of "minerals" - defined for legal purposes as the "valuable substances in the subsurface"
(Colorado Supreme Court, 2001) — has been of interest for a long time and is of interest in the Front Range area because of the conflicts that have arisen, and will likely continue to arise, out of questions about owner's rights. Originally, the Federal government claimed legal ownership of vast amounts of land in the Western U.S., including ownership of the minerals underlying the land. As the government granted some of this land to States, companies, and individuals in an attempt to encourage settlement, ownership of both the surface and the underlying minerals was transferred (Colorado Supreme Court, 2001). By this process the State of Colorado originally acquired 4.8 million acres of land from the Federal government when it became a State in 1876 (Colorado State Land Board, 2001).

Because ownership of the land and the underlying minerals as two entities is possible, it is also possible to sever ownership of one from the other (Colorado Supreme Court, 2001). Thus, ownership of one has been transferred through time without also transferring ownership of the other. In fact, it is possible to split the mineral rights so that various owners may have access to the various minerals found underneath a single parcel of land. An example of this would be different ownerships of the petroleum, water, and aggregate resources, all of which may reside under a parcel of land within the same or different geologic formations. Today, even if the owner of the land surface does understand that they may not own the rights to minerals under their land, it may be difficult to identify who owns those rights.

The owner or lessee of mineral rights is legally afforded ready access to the land surface area to explore for and develop mineral resources. Although the rights to the minerals supersede those of the surface owner, State statute, as well as city and county regulations, govern the way in which the owner or lessee of the mineral rights may use the land surface to access the minerals. In places, some land surface areas may not even be accessible for mineral development due to existing rules and regulations. This situation exists in the Greeley area, for example, where relatively dense urban development within the Greeley city limits has effectively precluded exploration and production of underlying oil and gas because State statute requires that wells be drilled at least 350 $\mathrm{ft}$ from an existing structure.

\section{Water Rights}

Water rights in Colorado are regulated under a system of strict appropriation referred to alternatively as the Colorado Doctrine or the Prior Appropriations Doctrine (Vranesh, 1989). Under this system, water rights are determined based on the principle of "first in time, first in right;" that is, older (senior) water rights have priority over younger (junior) water rights when meeting the needs of water users within a particular stream system. As long as enough water is available to meet the needs of all water users in a system, all may use the full amount of water legally appropriated to them. However, if the supply in a stream system is insufficient to meet the demands of all users, senior water rights must be satisfied before junior rights are fulfilled (Grantham, 1989). 
This system of appropriation, common in western States, contrasts with the Riparian Doctrine used in eastern States where surface water is more abundant (Vranesh, 1989). Under the Riparian Doctrine, owners of land adjacent to a stream or body of water have the right to use that water as long as the usage does not injure the rights of downstream users. The water right is appurtenant (adjunct) to the land and does not depend on prior use. Early farmers and miners quickly realized that the number of perennial streams in Colorado was insufficient to support the application of the Riparian system, so the system of Prior Appropriations was developed.

Under Colorado law, the water in every natural stream is considered to be public property, subject to appropriation for beneficial use by the people of the State. Beneficial use means that a reasonable amount of water is applied to some definite purpose, without waste. Examples of beneficial uses are domestic, household, livestock, irrigation, municipal, industrial, recreation, and wildlife.

Ground water that is considered tributary to a stream system, such as in alluvium and low terrace gravels along stream valleys, is regulated as part of the stream system and is subject to the doctrine of prior appropriations. Surface water rights have priorities dating from 1852, yet the majority of wells in the project area have been drilled since 1940; therefore, most ground-water appropriations have very junior rights (Robson, 1989). This fact, combined with the fact that water in the project area is overappropriated (that is, appropriations exceed supply), would make it virtually impossible to legally obtain water from new wells if it were not for legislation regarding augmentation plans, designated ground-water basins, nontributary ground water, and exempt wells.

\section{Role of Reclamation}

Mining reclamation involves altering the landscape from one produced by resource extraction to one that promotes a new land use. Production of oil and natural gas in the project area has a minimal effect on the land surface. Shallow underground coal mining practices and subsequent coal mine fires initiated land subsidence over old mines that is difficult or impossible to address by current reclamation technology. Where the development of water resources involves landscape modification, it is usually construction of permanent structures (dams, tunnels, reservoirs) rather than a temporary land usage that will eventually require reclamation. Production of aggregate resources, however, requires the removal of large volumes of material from the surface, creating pits and quarries that are obvious intrusions to the surrounding landscape. Reclamation is the process of converting these holes in the ground to a new land use.

Reclamation of exhausted aggregate mine sites is an essential activity that can have a positive impact on a region. Nearly all States require some level of mining reclamation, and responsible members of the mineral industry accept it as a part of doing business. The Colorado Mined Land Reclamation Act (State of Colorado, 1993) and the Colorado Land Reclamation Act for the Extraction of Construction Materials (State of Colorado, 1995) require an approved mining permit and reclamation plan before mining begins. Permit applications and reclamation plans must consider a variety of site characteristics including hydrology, geology, geochemical and geological hazards, land use and zoning, air quality, archeological, historical, and scenic features, vegetation, and wildlife habitat (Arbogast, 2001), as well as potential operational impacts such as noise, dust, truck traffic, and blasting effects.

Aggregate mining is a long-term activity. A sand and gravel pit in the project area may operate for 5-10 years before exhausting permitted reserves whereas a crushed stone quarry commonly operates for tens of years. Public opposition to aggregate mining is largely generated by the visual appearance of disturbed land. The promise of a reclamation project that will produce a land use that is viewed as necessary to the community or highly beneficial and desirable to the public may help to soften opposition and ensure continued availability of aggregate resources. An important role for the aggregate industry is to implement creative reclamation designs that integrate sound scientific practices with aesthetic and socioeconomic values of the public.

\section{Design Approaches}

Just as the laws regulating mining have changed over the years, so have approaches to reclamation design and the landscapes they produce. Reclamation can change an undesirable object in the landscape (pit or quarry) into a desirable public park, fishing lake, or local water storage facility. Nine different design approaches to mine reclamation can be recognized around the world: natural, camouflage, restoration, rehabilitation, mitigation, renewable resource, education, art, and integration (Arbogast, 1998; Arbogast and others, 2000). A combination of design approaches is most often used.

Reclaimed pits and quarries in the project area show elements of all of the design approaches except art.

Reclamation of the WREN (named after a Topeka, Kan., radio station) Pit near the Cache la Poudre River in Fort Collins, Colo., used an innovative natural design approach for the resto ration of native riparian vegetation to the mined area (Roelle and Gladwin, 1999; Roelle and others, 2001). After regrading to reduce side slopes, sloping the floor toward a drain, and establishing two islands, the pit was flooded by pumping and natural seepage (fig. 19). The water level was then gradually lowered during the time that native cottonwoods and willows were producing air-borne seeds. The cottonwoods and willows are adapted to germinate on the bare, moist surface. The process was repeated over 3 years at progressively lower water levels. Most nonnative and invasive species did not survive the flooding whereas the cottonwoods and willows thrived in the wetland environment. The reclaimed pit is now the Cottonwood Hollow Natural Area owned by the City of Fort Collins.

Developments such as housing, light industry, municipal water storage reservoirs, recreational lakes, and wildlife areas often obscure the previous land use (fig. 20). For many years, sand and gravel pits in the project area were abandoned or became landfill or water storage facilities. When refilled with refuse, returned to natural grade, and used for commercial development, the pits were no longer recognizable as past 


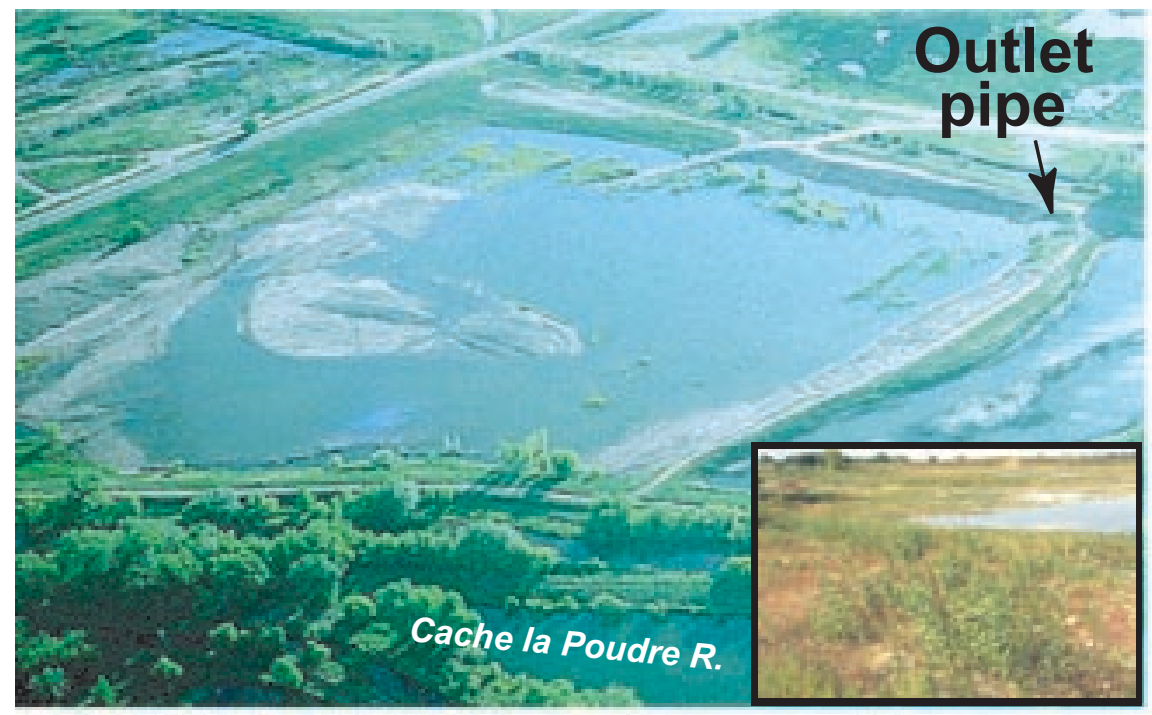

Figure 19. Aerial photograph of WREN Pit along Cache la Poudre River near Fort Collins, Colo., during initial flooding. Inset shows revegetation of pit with native willows and cottonwoods after water level in pit was gradually lowered.

mining areas—-they became "hidden landscapes." These hidden landscapes are common along the South Platte River and Clear Creek valleys (fig. 21).

At the Farm in Boulder County, gravel pits were reclaimed as wetlands, an example of mined-out lands being converted to renewable resources. More than 39,000 native plants were used to create a riparian ecosystem that also aided in the renewal of water resources (Leccese, 1996). Another example of renewable resource design is Lafarge Corporation's plan to mine and recycle concrete and asphalt construction rubble used years ago to fill an exhausted sand and gravel pit near Interstate 76 and Federal Boulevard. Nearby, a sanitary landfill (former sand and gravel mine) requires mitigation because it contains hazardous waste and is under State regulation (fig. 22).

Some of the most valuable real estate in Denver today began as open prairie, became agricultural land, then a sand and gravel operation, then a sanitary landfill, and finally a developed site. Cherry Creek shopping center, the old Mile High Stadium, Denver Coliseum, and Ruby Hill in Denver were all built on sanitary landfills, formerly sand and gravel pits, and are good examples of rehabilitation designs.

South Platte Park was developed on an area of extensive sand and gravel mining along the South Platte River valley in Littleton, Colo. The park, along with its Carson Nature Center, is an excellent example of a multi-design reclamation approach that includes education, mitigation, and integration. Lakes and ponds, native vegetation, abundant wildlife, and numerous hiking and biking trails provide a pleasant change from the surrounding urban environment (fig. 23).

\section{Future Directions}

As long as aggregate is produced along the Front Range urban corridor, exhausted pits and quarries will need to be reclaimed. With continued growth in the region, it is likely that mining and reclamation will need to coexist with urban and suburban environments and thoughtful reclamation projects will be even more important. Each mining site and its associated community present a unique combination of geology and societal views, preferences, and needs. Reclamation techniques and design guidelines are needed to help planners and policy-makers determine what to save, what to replace, and how to achieve a new land use that is best for the community.

A historical study that documented the evolution of the Clear Creek valley through the cycle of agriculture, aggregate mining, and reclamation during continued urban growth (Belinda Arbogast, USGS, written commun., 2001) shows that growth, mining, and reclamation will continue along the Front Range urban corridor whether it is planned or not. Planning the evolution of those stream valleys that have not yet been mined or developed to completion, including the Cache la Poudre and Big Thompson Rivers, the South Platte River north of Denver, and St. Vrain and Boulder Creeks, is an extremely difficult task, but planning will probably produce better long-term results than random chance.

\section{Epilogue}

Cities, counties, and the State of Colorado will be required to address a constant parade of difficult questions that affect the future availability of local infrastructure resources. Planning the best use of the land, both short term and long term, will involve a delicate balance between maintaining a certain quality of life, while ensuring the continued economic integrity of the region. The Front Range Infrastructure Resources Project has created a legacy of technical information, most of it in digital (electronic) format, on the location, distribution, and quality of natural aggregate, oil, natural gas, coal, and water resources in the project area. These types of data are required if planning is to consider the availability and cost of the infrastructure resources necessary to support and maintain the expanding society of this part of the Colorado Front Range urban corridor. 

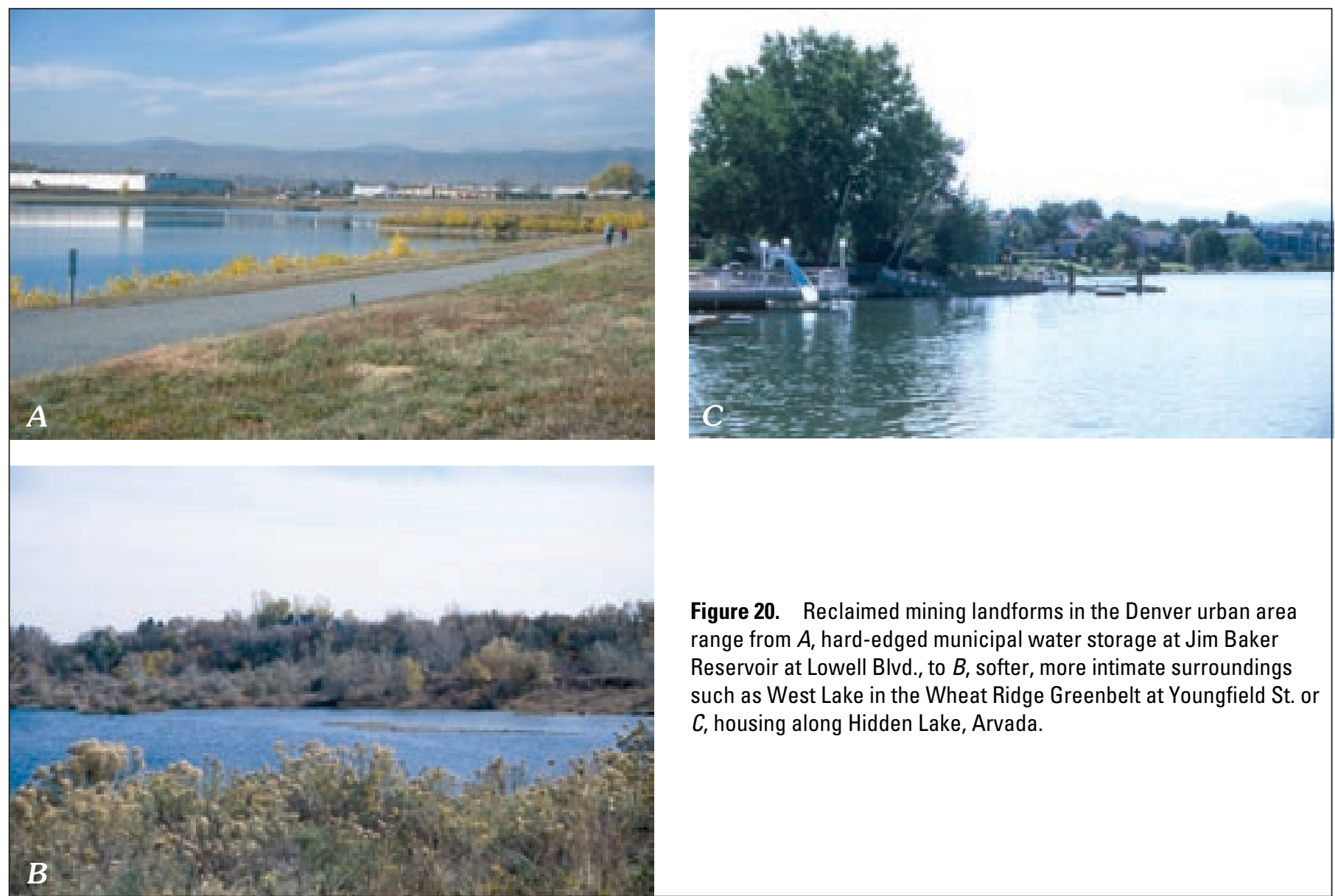

Figure 20. Reclaimed mining landforms in the Denver urban area range from $A$, hard-edged municipal water storage at Jim Baker Reservoir at Lowell Blvd., to $B$, softer, more intimate surroundings such as West Lake in the Wheat Ridge Greenbelt at Youngfield St. or $C$, housing along Hidden Lake, Arvada.

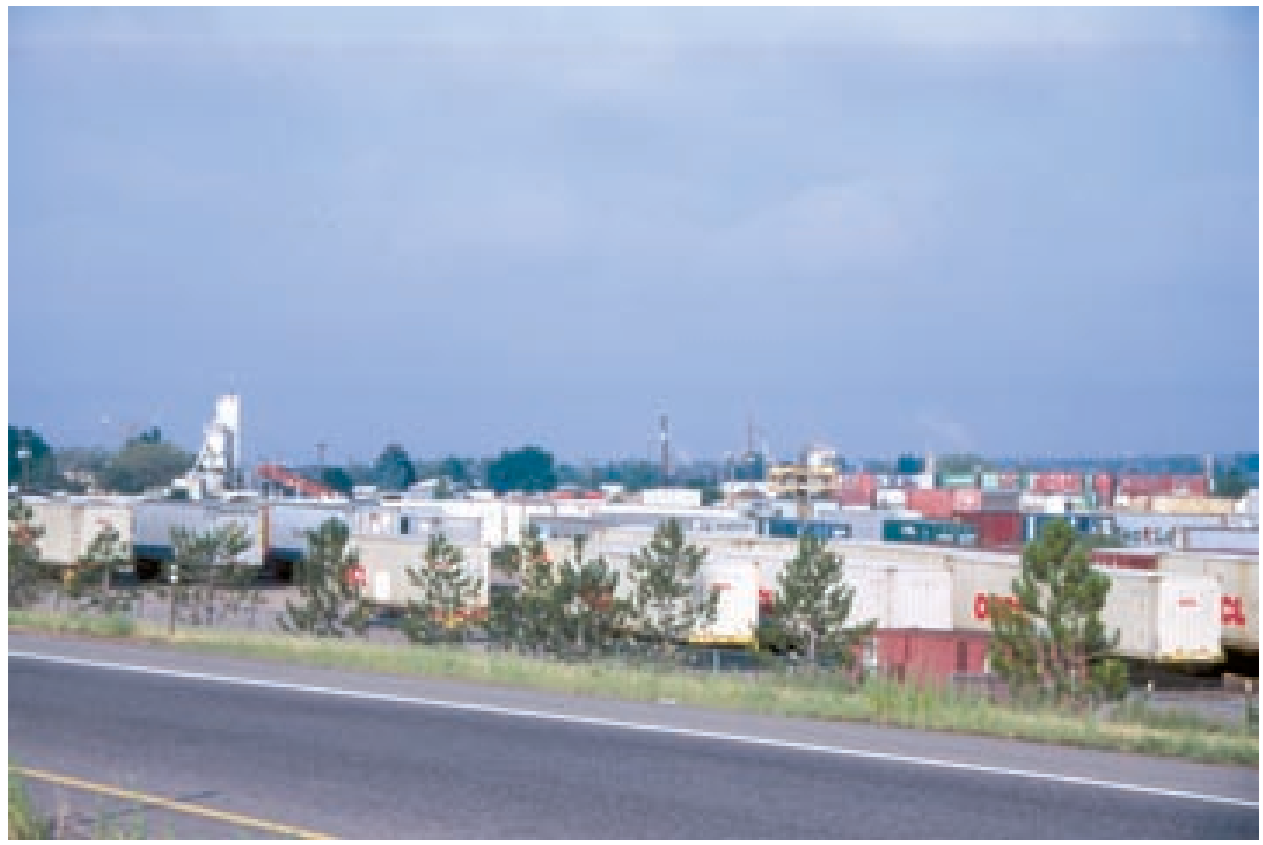

Figure 21. Storage area for shipping containers on a landfill graded to match the surrounding area along Interstate 76. There is little direct evidence of past sand and gravel mining activity that occurred in this "hidden landscape" or of its subsequent reclamation. 


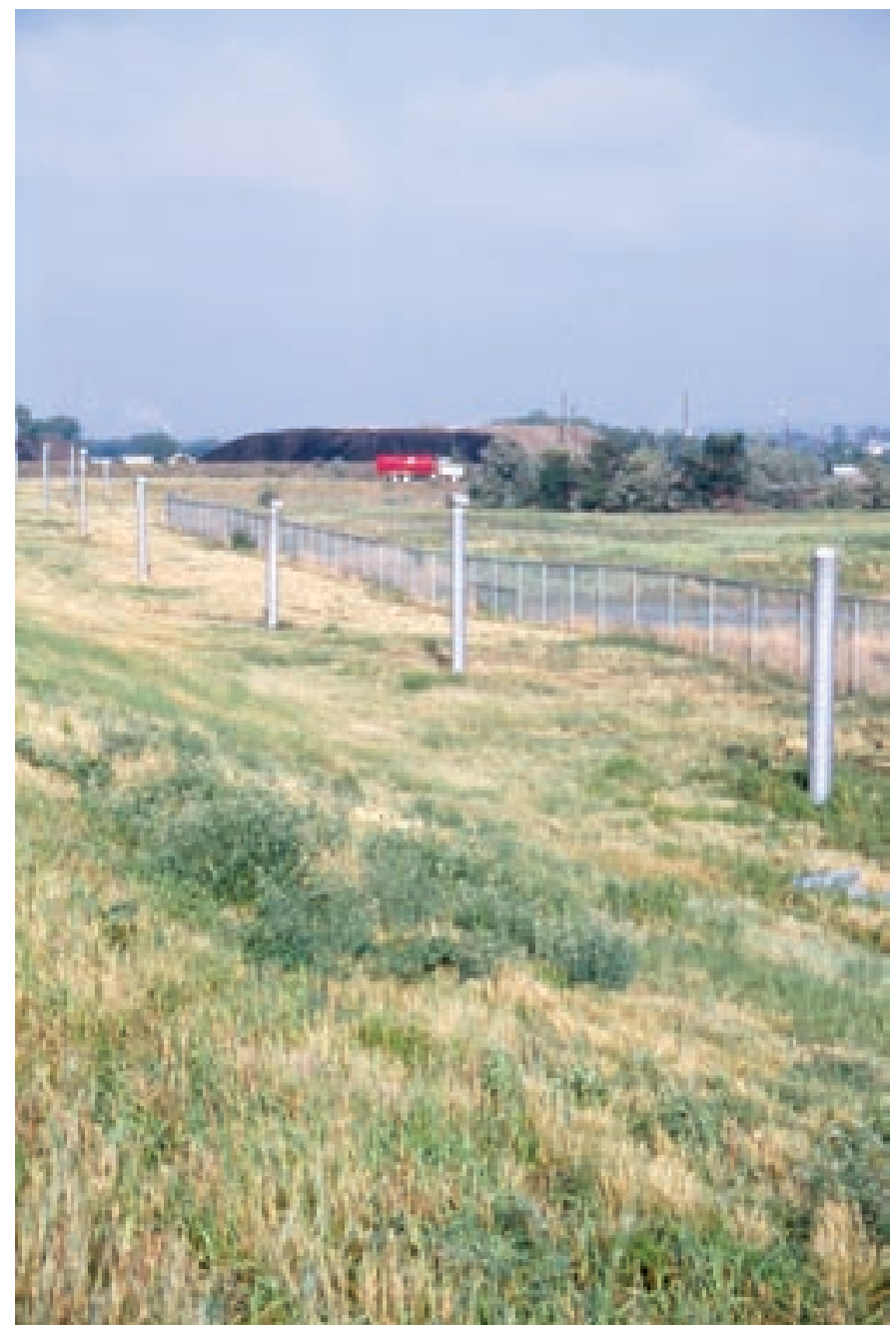

Figure 22. An older sanitary landfill in an exhausted sand and gravel pit near Interstate 76 and Pecos Street requires vents to allow methane gas to escape. Methane is generated from decomposing organic matter in landfill and its presence precludes other uses of land in near future.

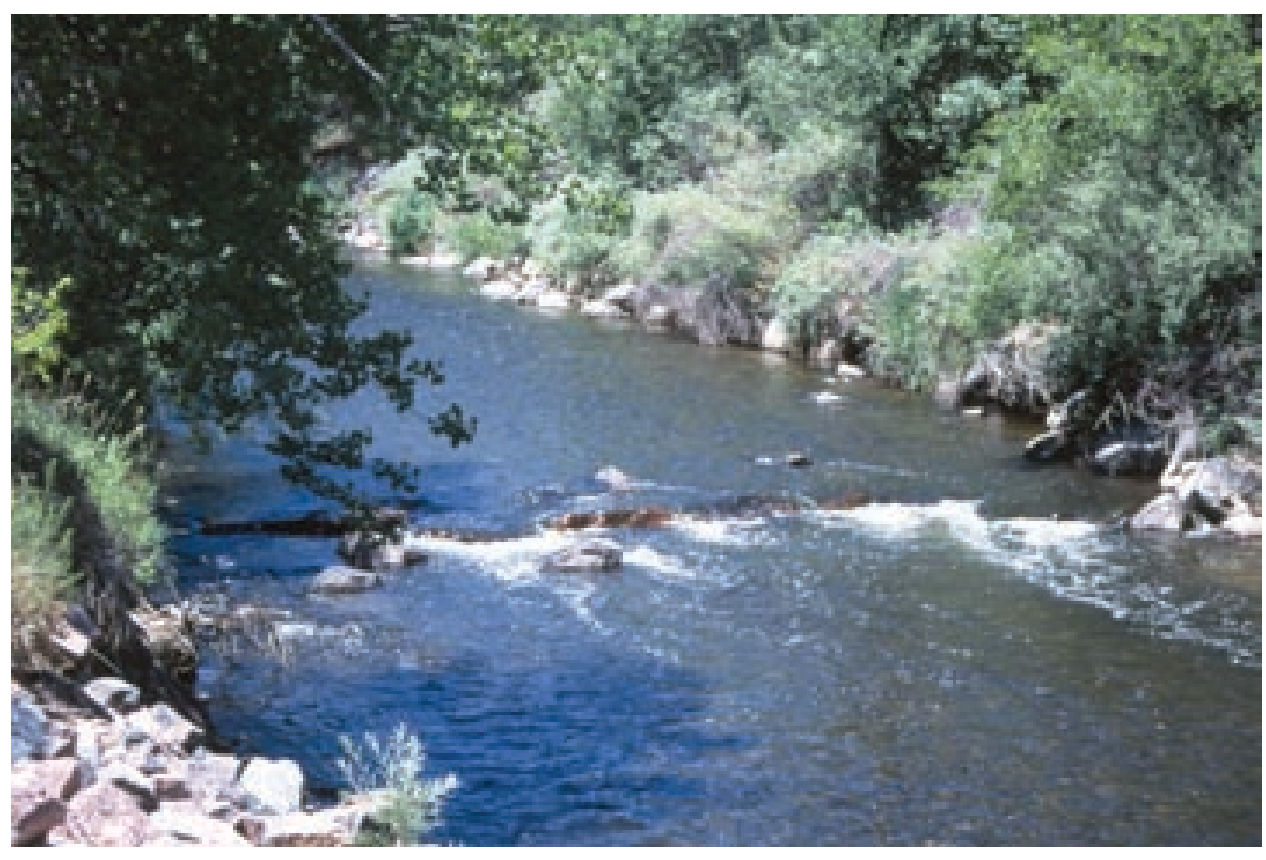

Figure 23. Reclaimed sand and gravel mining operations in Clear Creek valley at Prospect Park, Wheatridge, Colo., feature streamside riparian woodland vegetation and hiking and biking trails as well as adjacent ponds, picnic areas, and athletic fields. This multiuse facility is part of the greenbelt along Clear Creek that connects Golden, Colo., with the South Platte River. 


\section{References Cited}

Arbogast, B.F., 1998, Annotated bibliography of selected references on site design, environmental factors and regulations, and land use planning in mined land reclamation: U.S. Geological Survey OpenFile Report 98-144, 33 p.

2001, A review of reclamation law and the permitting process for surface mining in Colorado, in 37th Forum on the Geology of Industrial Minerals, Victoria, British Columbia, 2001, Program and Extended Abstracts: Victoria, British Columbia, British Columbia Ministry of Energy and Petroleum, p. 259.

_ in press, An overview of reclamation law dealing with mineral resource development in the United States of America, in Scott, P.W., and Bristow, C.M., eds., Industrial minerals and extractive industry geology, Proceedings of the 36th Forum on the Geology of Industrial Minerals and 11th Extractive Industry Geology Conference, Bath, England, 2000: Bath, England, Geological Society Publishing House.

Arbogast, B.F., Knepper, D.H., Jr., and Langer, W.H., 2000, The human factor in mining reclamation: U.S. Geological Survey Circular 1191, $28 \mathrm{p}$.

Carder, Carol, 1999, Demolition progressing at Denver's old Stapleton Airport: Rocky Mountain Construction, January 11, 1999, p. 82.

Carpenter, L.C., 1961, Florence-Canyon City field, in Parker, J.M., ed., Colorado-Nebraska oil and gas field volume: Rocky Mountain Association of Geologists volume X, p. 130-131.

Colorado Department of Local Affairs, 2000, Preliminary population projections for Colorado counties, 1990-2005. Accessed May 16, 2001 at URL http://wwwdola.state.co.us/demog/project.htm.

Colorado Department of Natural Resources, 2000, Denver Basin Ground Water Facts 2000: Denver, Colo., Division of Water Resources, 2 p.

Colorado State Land Board, 2001, A short history of the Colorado State Land Board. Accessed August 6, 2001 at URL http:// www.trustland.state.co.us/2000\%20annual\%20report/ slb_history.htm.

Colorado Supreme Court, 2001, Case announcement archive for 2000. Accessed August 6, 2001 at URL http://www.courts.state.co.us/ supct/caseann/11-28-00.htm.

Colton, R.B., and Fitch, H.R., 1974, Map showing potential sources of gravel and crushed-rock aggregate in the Boulder-Fort CollinsGreeley area, Front Range Urban Corridor, Colorado: U.S. Geological Survey Miscellaneous Investigations Series Map I-855-D, scale 1:100,000.

Crosby, 1978, Landforms in the Boulder-Fort Collins-Greeley area, Front Range Urban Corridor, Colorado: U.S. Geological Survey Miscellaneous Investigations Series Map I-855-H, 2 sheets, scale 1:100,000.

Dennehy, K.F., Litke, D.W., McMahon, P.B., Heiny, J.S., and Tate, C.M., 1995, Water-quality assessment of the South Platte River Basin, Colorado, Nebraska, and Wyoming - Analysis of available nutrient, suspended-sediment, and pesticide data, water years 1980-1992: U.S. Geological Survey Water-Resources Investigations Report 941095, $145 \mathrm{p}$.

Denver Regional Council of Governments, 2000, 2020 Regional Forecast Summary. Accessed November 28, 2000 at URL http:// www.drcog.org/reg_growth/reg_data/reg_4cst_sum.htm.

EIA, 2001, Energy Information Administration Historical Data. Accessed August 6, 2001 at URL http://www.eia.doe.gov/neic/historic/ historic.htm.
Fishman, N.S., Deszcz-Pan, M., Kucks, R.P., Roberts, S.B., Higley, D.K., Woodward, C.L., Otton, J.K., and Cook, T., 2001, Detection of oil, natural gas, and coal production infrastructure by magnetic surveys, Front Range of Colorado, in Symposium on the Application of Geophysics to Engineering and Environmental Problems (SAGEEP), Denver, Colo., 2001, Proceedings: Denver, Colo., Omnipress, CD$\mathrm{ROM}$, various pagination.

Fishman, N.S., Woodward, C.L., and Langer, W.H., 1999, Influence of the oil and gas production infrastructure on land use in the Front Range of Colorado, in Proceedings of the U.S. Geological Survey Front Range Infrastructure Resources Project Stakeholder's Meeting, 4 November 1998: U.S. Geological Survey Open-File Report 99-0001, p. 10-13.

Grantham, J.B., 1989, Synopsis of Colorado water law: State of Colorado, Division of Water Resources, $80 \mathrm{p}$.

Hedge, C.E., 1969, A petrogenetic and geochronologic study of migmatites and pegmatites in the central Front Range: Golden, Colo., Colorado School of Mines Ph.D. thesis, $158 \mathrm{p}$.

Hedge, C.E., Peterman, Z.E., and Braddock, W.A., 1967, Age of metamorphism in the northern Front Range, Colorado: Geological Society of America Bulletin, v. 78, p. 551-558.

Hemborg, H.T., 1993a, DB-5. Muddy ("J") Sand, in Atlas of major Rocky Mountain gas reservoirs: New Mexico Bureau of Mines and Mineral Resources, p. 113-114.

1993b, DB-2. Codell Sandstone and Niobrara Formation (Wattenberg area), in Atlas of major Rocky Mountain gas reservoirs: New Mexico Bureau of Mines and Mineral Resources, p. 107-108.

1993c, DB-3. Niobrara Chalk biogenic gas, in Atlas of major Rocky Mountain gas reservoirs: New Mexico Bureau of Mines and Mineral Resources, p. 111-112.

Herring, J.R., Roberts, S.B., and Hobbs, R.G., 1985, Characterization of extent of mining, mine fire, and subsidence-A case study at Marshall, Colorado, in Hynes, J.L., ed., Proceedings of the 1985 Conference on Coal Mine Subsidence in the Rocky Mountain Region: Colorado Geological Survey Special Publication 31, p. 39-80.

Higley, D.K., Pollastro, R.M., and Clayton, J.L., 1995, Denver Basin Province (039), in Gautier, D.L., Dolton, G.L., Takahashi, K.I., and Varnes, K.L., eds., National assessment of United States oil and gas resources-Results, methodology, and supporting data: U.S. Geological Survey Digital Data Series DDS-30, 1 CD-ROM.

Hynes, J.L., 1984, Tri-towns subsidence investigation, Weld County, Colorado-A community-wide approach to hazard evaluation and land use in undermined areas: Colorado Geological Survey Open File Report 87-3, $52 \mathrm{p}$.

1986, Essential components of a mine subsidence investigation, in Hynes, J.L., ed., Proceedings of the 1985 Conference on Coal Mine Subsidence in the Rocky Mountain Region: Colorado Geological Survey Special Publication 31, p. 81-86.

Kirkham, R.M., and Ladwig, L.R., 1979, Coal resources of the Denver and Cheyenne Basins, Colorado: Colorado Geological Survey Resource Series $5,70 \mathrm{p}$.

1980, Energy resources of the Denver and Cheyenne Basins, Colorado-Resource characterization, development potential, and environmental problems: Colorado Geological Survey Environmental Geology 12, $258 \mathrm{p}$.

Knepper, D.H., Jr., 2001, Annotated bibliography of the Front Range Infrastructure Resources Project-1996-2001: U.S. Geological Survey Open-File Report 01-302, 25 p. 
Knepper, D.H., Jr., Green, G.N., and Langer, W.H., 1999, Lithology and aggregate quality attributes for the digital geologic map of Colorado: U.S. Geological Survey Open-File Report 99-29, 1 CD-ROM.

Langer, W.H., and Lindsey, D.A., 1999, Preliminary deposit models for sand and gravel in the Cache la Poudre River valley: U.S. Geological Survey Open-File Report 99-587, 27 p.

Langer, W.H., Lindsey, D.A., and Knepper, D.H., Jr., 1999, A GIS and decision support system demonstration of aggregate maps and data for the Front Range Infrastructure Resources Project area, in Johnson, K.S., ed., 34th Forum on the Geology of Industrial Minerals, Norman, Okla., 1998, Proceedings: Norman, Okla., Oklahoma Geological Survey Circular 102, p. 139-146.

Leccese, Michael, 1996, Little marsh on the prairie: Landscape Architecture, v. 86, no. 7, p. 50-55.

Lindsey, D.A., 1997, Introduction to sand and gravel deposit models, Front Range, Colorado: U.S. Geological Survey Open-File Report 97-81, 6 p.

Matheson, G.M., and Bliss, Z.F., 1986, Observations on the location of chimney subsidence sinkhole development along the Colorado Front Range, in Hynes, J.L., ed., Proceedings of the 1985 Conference on Coal Mine Subsidence in the Rocky Mountain Region: Colorado Geological Survey Special Publication 31, p. 169-190.

Myers, A.R., Hansen, J.B., Lindvall, R.A., Ivey, J.B., and Hynes, J.L., 1975, Coal mine subsidence and land use in the Boulder-Weld coalfield, Boulder and Weld Counties, Colorado: Prepared by Amuedo and Ivey (consultants) for the Colorado Geological Survey; published as Environmental Geology Series EG-9, 88 p.

National Academy of Sciences, 1980, Surface mining of non-coal minerals-Appendix I-Sand and gravel mining, and quarrying and blasting for crushed stone and other construction minerals: Washington, D.C., National Academy of Sciences, $90 \mathrm{p}$.

Phillips, R.A., and Holmquist, D.V., 1986, Backfilling of the Pikeview Mine Manway, in Hynes, J.L., ed., Proceedings of the 1985 Conference on Coal Mine Subsidence in the Rocky Mountain Region: Colorado Geological Survey Special Publication 31, p. 39-80.

Roberts, L.N.R., and Kirschbaum, M.A., 1995, Paleogeography of the Late Cretaceous of the Western Interior of Middle North America-Coal distribution and sediment accumulation: U.S. Geological Survey Professional Paper 1561, $115 \mathrm{p}$.

Roberts, S.B., and Fishman, N.S., 2000, Coal-bed methane potential in the Laramie Formation, greater Wattenberg area, Denver Basin, Colorado-Just wishful thinking?: American Association of Petroleum Geologists, v. 84, p. 1245.

Roberts, S.B., Hynes, J.L., and Woodward, C.L., 2001, Maps showing the extent of mining, locations of mine shafts, adits, airshafts, and bedrock faults, and thickness of overburden above abandoned coal mines in the Boulder-Weld coal field, Boulder, Weld, and Adams Counties, Colorado: U.S. Geological Survey Geologic Investigations Series I-2735, scale 1:48,000.

Robson, S.G., 1989, Alluvial and bedrock aquifers of the Denver BasinEastern Colorado's dual ground-water resource: U.S. Geological Survey Water-Supply Paper 2302, 40 p.

1996, Geohydrology of the shallow aquifers in the Denver metropolitan area, Colorado: U.S. Geological Survey Hydrologic Investigations Atlas HA-736, 5 sheets, scale 1:50,000.

Robson, S.G., Arnold, L.R., and Heiny, J.S., 2000a, Geohydrology of the shallow aquifers in the Greeley-Nunn area, Colorado: U.S. Geological Survey Hydrologic Investigations Atlas HA-746-A, 5 sheets, scale $1: 50,000$. 2000b, Geohydrology of the shallow aquifers in the Fort CollinsLoveland area, Colorado: U.S. Geological Survey Hydrologic Investigations Atlas HA-746-B, 5 sheets, scale 1:50,000.

Robson, S.G., and Banta, E.R., 1995, Ground water atlas of the United States segment 2: U.S. Geological Survey Hydrologic Investigations Atlas HA-730-C, $32 \mathrm{p}$.

Robson, S.G., and Heiny, J.S., 1998, Front Range Infrastructure Resources Project water resources activities: U.S. Geological Survey Fact Sheet 113-98, $4 \mathrm{p}$.

Robson, S.G., Heiny, J.S., and Arnold, L.R., 2000a, Geohydrology of the shallow aquifers in the Fort Lupton-Gilcrest area, Colorado: U.S. Geological Survey Hydrologic Investigations Atlas HA-746-C, 5 sheets, scale 1:50,000.

2000b, Geohydrology of the shallow aquifers in the BoulderLongmont area, Colorado: U.S. Geological Survey Hydrologic Investigations Atlas HA-746-D, 5 sheets, scale 1:50,000.

Robson, S.G., Van Slyke, George, and Graham, Glenn, 1998, Structure, outcrop, and subcrop of the bedrock aquifers along the western margin of the Denver Basin, Colorado: U.S. Geological Survey Hydrologic Investigations Atlas HA-742, 5 sheets, scale 1:50,000.

Rodriguez, B.D., 1983, A self-potential investigation of a coal mine fire: Golden, Colo., Colorado School of Mines M.S. thesis, $132 \mathrm{p}$.

Roelle, J.E., and Gladwin, D.N., 1999, Establishment of woody riparian species from natural seedfall at a former gravel pit: Restoration Ecology, v. 7, no. 2, p. 183-193.

Roelle, J.E., Gladwin, D.N., and Cade, B.S., 2001, Establishment, growth, and early survival of woody riparian species in Colorado: Great Basin Naturalist, v. 61, no. 2, p. 192-194.

Schwochow, S.D., 1980, The effects of mineral conservation legislation on Colorado's aggregate industry, in Proceedings of the Fifteenth Forum on Geology of Industrial Minerals: Colorado Geological Survey Resource Series no. 8, p. 30-39.

Schwochow, S.D., Shroba, R.R., and Wicklein, P.C., 1974a, Atlas of sand, gravel, and quarry aggregate resources, Colorado Front Range Counties: Colorado Geological Survey Special Publication 5B, 43 p.

1974b, Atlas of sand, gravel, and quarry aggregate resources, Colorado Front Range Counties: Colorado Geological Survey Special Publication 5B, digitized and compiled by Cappa, J.A., Hiatt, C.S., Litke, D.W., McCormick, M.L., and Sadlick, Joseph, 2000: Colorado Geological Survey and U.S. Geological Survey Open-File Report 00-9, 1 CD-ROM.

Sheridan, M.J., 1967, Urbanization and its impact on the mineral aggregate industry in the Denver, Colo., area: U.S. Bureau of Mines IC $8320,53 \mathrm{p}$.

Sherman, G.D., 1986, Assessment of subsidence related damage to structures in Louisville and Lafayette, Colorado, in Hynes, J.L., ed., Proceedings of the 1985 Conference on Coal Mine Subsidence in the Rocky Mountain Region: Colorado Geological Survey Special Publication 31, p. 87-96.

State of Colorado, 1993, Senate Bill 93-247, Colorado Mined Land Reclamation Act, 34-32-101 et seq., C.R.S. 1973 as amended, 47 p.

1995, Senate Bill 95-156, Colorado Land Reclamation Act for the Extraction of Construction Materials, $134 \mathrm{p}$.

Tremain, C.M., Hornbaker, A.L., Holt, R.D., Murray, D.K., and Ladwig, L.R., 1996, 1995 summary of coal resources in Colorado: Colorado Geological Survey Special Publication 41, 19 p.

Tweto, Ogden, 1975, Laramide (Late Cretaceous-Early Tertiary) Orogeny in the southern Rocky Mountains, in Scott, G.R., ed., Cenozoic 
surfaces and deposits in the Southern Rocky Mountains: Geological Society of America Memoir 144, p. 1-43.

U.S. Department of Labor, 1981, Report to the Denver Construction Committee on sand and gravel operations at Chatfield Dam and Recreation Area: U.S. Department of Labor, Office of Construction Industry Services, 4 p., and exhibits A-I.

U.S. Geological Survey, 1999, Recycled aggregates-Profitable resource conservation: U.S. Geological Survey Fact Sheet FS-18199, February 2000, 2 p.

2001a, High-Resolution Land Use and Land Cover 1937/1938 Front Range Infrastructure Resources Project Demonstration Area, Rocky Mountain Mapping Center, Lakewood, Colo. Accessed September 1, 2001 at URL http://rockyweb.cr.usgs.gov/frontrange/NMD/data/ lu30.html.

2001b, High-Resolution Land Use and Land Cover 1996/1997 Front Range Infrastructure Resources Project Demonstration Area, Rocky Mountain Mapping Center, Lakewood, Colo. Accessed September
1, 2001 at URL http://rockyweb.cr.usgs.gov/frontrange/NMD/data/ lu90.html.

U.S. Interagency Working Group on Industrial Ecology, Material and Energy Flows, 1999, Materials: Washington, D.C., November 1999, 29 p.

Van Horn, Richard, 1957, Bedrock geology of the Golden quadrangle, Colorado: U.S. Geological Survey Geologic Quadrangle Map GQ-103, scale $1: 24,000$.

Vranesh, George, 1989, Colorado citizens' water law handbook: Boulder, Colo., Design Press, 63 p.

Weimer, R.J., 1996, Guide to the petroleum geology and Laramide orogeny, Denver Basin and Front Range, Colorado: Colorado Geological Survey Bulletin 51, $127 \mathrm{p}$.

Wilburn, D.R., and Goonan, T.G., 1998, Aggregates from natural and recycled sources: Economic assessments for construction applications-A materials flow analysis: U.S. Geological Survey Circular 1176, 37 p. Available at URL http://geology.cr.usgs.gov/pub/ circulars/c1176/ 